\title{
Bee Viruses: Routes of Infection in Hymenoptera
}

\author{
Orlando Yañez ${ }^{1,2 *}$, Niels Piot ${ }^{3}$, Anne Dalmon ${ }^{4}$, Joachim R. de Miranda ${ }^{5}$, \\ Panuwan Chantawannakul6,7, Delphine Panziera ${ }^{8,9}$, Esmaeil Amirit $^{10,11}$, Guy Smagghe ${ }^{3}$, \\ Declan Schroeder ${ }^{12,13}$ and Nor Chejanovsky ${ }^{14 *}$
}

${ }^{1}$ Institute of Bee Health, Vetsuisse Faculty, University of Bern, Bern, Switzerland, ${ }^{2}$ Agroscope, Swiss Bee Research Centre, Bern, Switzerland, ${ }^{3}$ Laboratory of Agrozoology, Department of Plants and Crops, Faculty of Bioscience Engineering, Ghent University, Ghent, Belgium, ${ }^{4}$ INRAE, Unité de Recherche Abeilles et Environnement, Avignon, France, ${ }^{5}$ Department of Ecology, Swedish University of Agricultural Sciences, Uppsala, Sweden, ${ }^{6}$ Environmental Science Research Center, Faculty of Science, Chiang Mai University, Chiang Mai, Thailand, ${ }^{7}$ Department of Biology, Faculty of Science, Chiang Mai University, Chiang Mai, Thailand, ${ }^{8}$ General Zoology, Institute for Biology, Martin-Luther-University of Halle-Wittenberg, Halle (Saale), Germany, ${ }^{9}$ Halle-Jena-Leipzig, German Centre for Integrative Biodiversity Research (iDiv), Leipzig, Germany, ${ }^{10}$ Department of Biology, University of North Carolina at Greensboro, Greensboro, NC, United States, ${ }^{11}$ Department of Entomology and Plant Pathology, North Carolina State University, Raleigh, NC, United States, ${ }^{12}$ Department of Veterinary Population Medicine, College of Veterinary Medicine, University of Minnesota, Saint Paul, MN, United States, ${ }^{13}$ School of Biological Sciences, University of Reading, Reading, United Kingdom, ${ }^{14}$ Entomology Department, Institute of Plant Protection, The Volcani Center, Rishon LeZion, Israel

Numerous studies have recently reported on the discovery of bee viruses in different arthropod species and their possible transmission routes, vastly increasing our understanding of these viruses and their distribution. Here, we review the current literature on the recent advances in understanding the transmission of viruses, both on the presence of bee viruses in Apis and non-Apis bee species and on the discovery of previously unknown bee viruses. The natural transmission of bee viruses will be discussed among different bee species and other insects. Finally, the research potential of in vivo (host organisms) and in vitro (cell lines) serial passages of bee viruses is discussed, from the perspective of the host-virus landscape changes and potential transmission routes for emerging bee virus infections.

Keywords: bee, virus, transmission, Apis, non-Apis, natural infection, artificial infection

\section{INTRODUCTION}

Viruses are omnipresent in practically all life forms, where they pose a potential threat to the health of the organism. This also applies for the viruses found in bees. Most of these viruses were originally discovered in honey bees, either through symptoms or diseases associated with infection. Some honey bee viruses can be propagated in, as well as isolated and purified from honey bee pupae. This enabled the initial characterization of the viruses and the development of diagnostic assays. With these early diagnostic assays, it was shown even then that these "honey bee viruses" could also be detected in other bee species and wasps, although no systematic host-range study has ever been conducted. However, recent studies found that those viruses are much more common and widespread than previously suspected, occurring in numerous other hymenopteran and non-hymenopteran arthropods. Furthermore, there are reports of spillover from and between hymenopteran taxa and non-hymenopteran arthropods. Knowing the different possible virus transmission routes and their potential host-range is key to understanding 
prevalence, epidemiology and virulence in different bee species. Numerous studies have recently reported the discovery and transmission routes of viruses in different arthropod species, including many bee species. The aim of this review is to provide an overview of the recent advances of the impact and transmission of viruses found in bees. We have divided this review into two main parts. The first part, 'Natural infections,' summarizes the current knowledge regarding natural infections and the transmission routes of viruses found in honey bees. The second part, 'Artificial infections', provides an overview of the studies involving controlled experimental virus infections and transmission. The major modes and routes of virus transmission in bees are summarized in Box $\mathbf{1}$.

\section{PART 1: NATURAL INFECTIONS}

Most of our understanding about natural bee virus infections came from studies with honey bees, particularly Apis mellifera. A big part of the recent developments in this field allowed for the expansion in knowledge of virus infections in other bee species. Most of these new developments involve bee species that can either be easily reared or are used for commercial pollination services, such as bumble bees (Bombus spp.), stingless bees (e.g., Melipona spp.), mason bees (e.g., Osmia spp.) and leafcutter bees (e.g., Megachile spp.). This section is therefore divided into five subsections: transmission of viruses in Apis mellifera, distribution of bee viruses in other Apis species, recently discovered bee viruses, transmission of bee viruses in non-Apis pollinators and transmission of viruses in non-bee insects.

\section{Transmission of Viruses in Apis mellifera Horizontal Transmission \\ Oral-fecal}

This route is arguably the most common route for bee virus transmission, both within honey bee colonies and between bee species (Figueroa et al., 2019). There are diverse and abundant evidence that supports this route of transmission for most viruses found in honey bees. Most bee viruses are shed in copious amounts into the feces, from where they are released into the environment and can be picked up by other bees, through floral networks (Figueroa et al., 2019). Feces are also sometimes shed within bee colonies, particularly when the weather (cold, rain, wind) prevents cleansing flights or when the bees suffer from diarrhea, usually due to indigestible compounds in honey or pollen, or for suffering from nosemosis, a disease caused by Nosema sp. Bees complete the transmission when attempting to remove these feces as part of their cleaning activities.

\section{Trophallaxis}

A foodborne transmission pathway involving trophallaxis (mouth-to-mouth sharing of food between colony members) was proposed to exist for Israeli acute paralysis virus (IAPV; Chen et al., 2014). Laboratory experiments showed that IAPV can indeed be acquired through trophallaxis (Amiri et al., 2019), but it is not known if this transmission also leads to infection.
BOX 1| Virus transmission routes - Definitions for the present review.

Horizontal transmission is the transmission of infectious agents among individuals of the same generation. Horizontal transmission of viruses in honey bees includes transmission to different bee developmental stages via oral and/or body contact. It includes indirect infections through contaminated food (food-borne transmission) and contact with feces; venereal transmission, where virus is transmitted from drones to queens during the nuptial flights or by artificial insemination, and vector-mediated transmission, where

transmission is mediated by other organisms (vectors). This vector can either be a mechanical or biological vector. A mechanical vector is defined as an organism that transmits viruses without being infected itself, while in a biological vector the virus replicates in the vector organism before being transmitted.

Vertical transmission consists of the transmission of viruses to the next generation, which for honey bees is primarily from queens to their eggs. This transmission can be defined as either transovum or transovarial transmission, depending on whether viruses are transmitted on the egg surface or within the egg, respectively. A second form of vertical transmission is transspermal transmission, if the virus is present inside the sperm, which would be the drone equivalent of transovarial transmission. This has so far not been detected in honey bees.

Transmission is defined as the establishment of a new infection in a previously non-infected individual, after acquiring the virus inoculum directly from another infected individual, from a vector or indirectly from the environment. It excludes any passive acquisition or retention of virus inoculum that does not cause infection of the bodily tissues.

\section{Hypopharyngeal glands and larval food}

The hypopharyngeal glands are paired tubular secretory organs in the frontal region of the worker bee head (Snodgrass, 1956). They secrete a proteinaceous substance, royal jelly, which is the principal component of larval food. Several viruses have been detected from worker bees hypopharyngeal glands and larval food indicating a potential virus transmission route. Acute bee paralysis virus (ABPV) is frequently detected in the hypopharyngeal glands of ABPV-symptomatic adults (Bailey and Milne, 1969). IAPV, a closely related virus of ABPV (de Miranda et al., 2010a), was also found at relatively high levels in hypopharyngeal glands (Chen et al., 2014). Deformed wing virus (DWV) has also been detected in the glandular secretions of nurse bees (Fievet et al., 2006) and in larval food (Yue and Genersch, 2005). Kashmir bee virus (KBV) and Sacbrood virus (SBV) have been detected in larval food (Shen et al., 2005a). The large amounts of Cloudy wing virus (CWV) in sealed brood suggest an oral transmission route, i.e., that nurse bees infected with CWV can transmit the virus to larva via the larval food (Carreck et al., 2010).

\section{Other food sources}

The detection of viruses in food sources (i.e., brood food, honey, pollen) also suggests an oral transmission route. KBV and SBV have been detected in honey, pollen, and royal jelly (Bailey and Fernando, 1972; Singh et al., 2010). Apis mellifera filamentous virus (AmFV) has been detected in honey and pollen (Gauthier et al., 2015). IAPV was found in pollen (Chen et al., 2014) while Black queen cell virus (BQCV), Lake Sinai virus (LSV), DWV, and SBV have been detected in pollen pellets (Singh et al., 2010; Ravoet et al., 2015a). 


\section{Detection in gut tissues and feces}

Black queen cell virus was detected in queen gut tissues and feces, suggesting possible transmission through feces (Chen et al., 2006). However, BQCV seems to be partially dependent on Nosema apis for infection of adult bees by ingestion (Bailey et al., 1983a). Several other viruses have been detected in the feces of infected bees such as ABPV (Bailey and Gibbs, 1964), Chronic bee paralysis virus (CBPV; Bailey, 1965), DWV (Chen et al., 2006), KBV (Hung, 2000), IAPV (Chen et al., 2014), and CBPV contaminated feces have recently been proven to provoke CBPV infection and overt disease in naive bees placed in cages previously occupied with contaminated individuals (Ribière et al., 2007).

\section{Topical or body contact}

Chronic bee paralysis virus can be transmitted by topical application on newly denuded honey bee cuticula (Bailey et al., 1983b) and it is transmitted from contaminated bees to noninfected bees reared in the same cages (Amiri et al., 2014; Coulon et al., 2018). Similarly, IAPV can be transmitted by topical application to honey bee workers and subsequent physical contact between infected workers and queens that leads to highly infected queens, suggesting that IAPV can also spread through close bodily contact (Amiri et al., 2019).

\section{Vector-mediated transmission}

Virus transmission via another organism (a 'vector') is also considered a form of horizontal transmission, since it still concerns transmission between individuals of the same generation. The close interaction between honey bees with obligate parasites such as endo- and ectoparasitic mites create a scenario where such mites can act as either mechanical vectors (i.e., exclusively the physical transfer of the acquired virus to a new host) or even biological vectors (where the virus also replicates inside the vector) for viruses (Chantawannakul et al., 2006; Forsgren et al., 2009). Picorna-like virus particle aggregations were found in lysed cells from the body cavity of the tracheal mite, Acarapis woodi (Liu, 1991) which is an endoparasitic mite that lives inside the tracheae and air sacs of adult honey bees (Sammataro et al., 2000). Although the identity of the virus was not established, the particle sizes and shapes are one of the most common ones among insect viruses. The role of A. woodi as a vector for picorna-like viruses is still unclear, mostly because very little dedicated research has been conducted on the possible role of $A$. woodi as a vector of virus diseases, in part because in the past it has never been linked to any viral disease.

By contrast, there is abundant evidence for vectored virus transmission by the ectoparasitic mite Varroa destructor (Santillán-Galicia et al., 2010; Möckel et al., 2011; Martin et al., 2012; Gisder et al., 2018; Posada-Florez et al., 2019; Ryabov et al., 2019), which is the reason why this mite is currently the most damaging parasite of the honey bees (Rosenkranz et al., 2010). ABPV, KBV, and IAPV are part of a complex of related viruses (Chen and Siede, 2007; de Miranda et al., 2010b), sometimes referred to as the "AKI complex." These viruses have been associated with honey bee colony losses, particularly when colonies are co-infected with $V$. destructor (Cox-Foster et al.,
2007; de Miranda et al., 2010a; Dainat et al., 2012). As yet, there has not been any direct evidence of ABPV replication within varroa mites (Ball, 1983, 1985; de Miranda et al., 2010b). However, high levels of ABPV have been detected in individual varroa-parasitized bees, as well as in entire honey bee colonies, indicating that the mite functions as a mechanical vector of $A B P V$ (Bakonyi et al., 2002; D'Alvise et al., 2019). Effective transmission by $V$. destructor mites to a new host occurs after $36 \mathrm{~h}$ of acquiring the virus. DWV is widely detected in colonies infested by $V$. destructor. The mites function as a mechanical vector of DWV as they can transmit DWV during feeding activities (Ball, 1989; Bowen-Walker et al., 1999; Nordström, 2003; Shen et al., 2005b). Moreover, $V$. destructor has been described as a biological vector of DWV since the virus multiplies inside the vector, which is linked to the subsequent appearance of overt DWV infections in emerging bees (Gisder et al., 2009). DWV is a quasispecies made up of a cloud of variants. These variants can be divided into three master variants, DWV-A, B, and -C (Mordecai et al., 2016c). The latest evidence suggests that DWV-B replicates inside V. destructor (Ongus et al., 2004; Campbell et al., 2016; Posada-Florez et al., 2019). DWV-B was originally named Varroa destructor virus 1 that was shown to be virulent when injected in high-titers into pupae or adult bees in cage experiments (Ryabov et al., 2014, 2019; McMahon et al., 2016; Gisder et al., 2018) but had surprisingly protective features when dominant in a colony despite the presence of $V$. destructor (Mordecai et al., 2016a). Interestingly, a positive correlation of DWV-B with bees dying over the winter period in stationary colonies were observed (Natsopoulou et al., 2017), however, these colonies nonetheless survived the overwintering period and did not collapse the following spring. This was not the case when colonies with high-titers of DWV-A and possibly DWV-C resulted in unexpected colony losses over the same overwintering period (Kevill et al., 2017). DWV-A is proposed to be mechanically vectored by $V$. destructor as it could only be transferred in lab-based experiments in a non-propagative manner (Posada-Florez et al., 2019).

Israeli acute paralysis virus is also widely detected in colonies infested by $V$. destructor mites. Evidence shows that $V$. destructor mites serve as an effective mechanical and biological vector of IAPV (Di Prisco et al., 2011). The detection of KBV in $V$. destructor mites and their salivary secretions (Hung and Shimanuki, 1999; Hung, 2000; Shen et al., 2005b) suggests that the parasite may act as a vector of KBV. CBPV was also detected in $V$. destructor, and the mite was involved in CBPV infection within the hive (Celle et al., 2008). V. destructor was also proven to acquire Slow bee paralysis virus (SBPV) by feeding on infected pupae and subsequently transmitting the virus to new parasitized pupae (Santillán-Galicia et al., 2010). V. destructor was proposed to be a biological vector for Apis rhabdovirus1/Bee rhabdovirus-1 (ARV-1/BRV-1). Although replication of intermediate forms for these viruses were detected in varroa mites (Levin et al., 2017), the fact that much of the $V$. destructor gut contents, including nucleic acids and possible virus replication intermediate forms, are derived from their bee hosts (Cornman, 2017; Posada-Florez et al., 2019), means that such evidence is not necessarily conclusive for biological vector status of the mite 
(see also de Miranda et al., 2015). Nevertheless, Remnant et al. (2017) proposed that $V$. destructor is a genuine host for ARV-1 and -2 because the ssRNA (small RNA) profile of these viruses found in mites were different from those found in honey bees. $V$. destructor-mediated transmission of LSV is also suspected, as the virus is readily detected in the mite, although no causal association has been shown thus far (Daughenbaugh et al., 2015; Ravoet et al., 2015a). Bee Macula-like virus (BeeMLV) is also strongly correlated with the presence of $V$. destructor. It was shown to replicate in bees, and thus accumulate replication intermediates in mites (de Miranda et al., 2015). More conclusive evidence is needed to elucidate the precise role of mites in the transmission of this virus (de Miranda et al., 2015). Similarly, there is no conclusive evidence that SBV is directly transmitted by $V$. destructor, although it is frequently associated with varroarelated damage (Dubois et al., 2020), host-virus molecular interactions (Di Prisco et al., 2016; Ryabov et al., 2016; Remnant et al., 2019) and tolerance (Thaduri et al., 2018) as well as in $V$. destructor behavior (Giuffre et al., 2019). For BQCV, there is no evidence that it replicates in or is transmitted by $V$. destructor.

As in the case of the $V$. destructor - Apis mellifera relationship, Tropilaelaps mites are also ectoparasitic mites that are native to Asia and naturally parasitise Apis dorsata. Two species of Tropilaelaps mites (Tropilaelaps mercedesae and $T$. clareae) are also able to parasitise Apis mellifera. Compared with $V$. destructor, $T$. mercedesae is much more dependent on the continuous availability of honey bee brood for feeding and reproduction (Chantawannakul et al., 2016). T. mercedesae was also shown to transmit DWV in honey bees (Dainat et al., 2009; Forsgren et al., 2009; Khongphinitbunjong et al., 2016; Wu et al., 2017) and was associated with clinical DWV symptoms, such as reduced longevity, reduced weight at emergence and crippled wings (Khongphinitbunjong et al., 2016). ABPV, another common honey bee virus, has also been detected in $T$. mercedesae, with phylogenetic analyses implying that ABPV might have moved from T. mercedesae to A. mellifera (Chanpanitkitchote et al., 2018).

Aethina tumida, the small hive beetle (SHB), is a scavenger of honey bee colonies, whose larvae feed on honey, pollen and detritus. It has been shown that SHB can acquire DWV by feeding on DWV-infected brood and bees, by topical contact with DWVcontaminated wax and by exploiting trophallaxis between bees. The occurrence of high DWV titers in SHB suggests that it could be a true host, and possible biological reservoir, for DWV. Since SHB consumes bees, the detection of DWV replication intermediates (negative-strand RNA) is by itself not conclusive evidence for biological-vector status, similar as for varroa, but supports the evidence of quantitative increase in DWV titers (Eyer et al., 2009).

\section{Venereal transmission}

Venereal transmission is also considered a form of horizontal transmission, since it involves individuals from the same generation. Because of the challenges in experimentally controlling the natural mating process of honey bee queens and drones, much of the evidence for venereal infection is based on experiments with artificial insemination (Yue et al., 2006; de Miranda and Fries, 2008) the detection of viral particles in the reproductive organs, tissues and secretions of drones and queens (e.g., endophallus, semen, ovaries, spermatheca). That is the case for the detection of ABPV (Yue et al., 2006; Prodělalová et al., 2019), BQCV (Prodělalová et al., 2019), SBV (Prodělalová et al., 2019), AmFV (Gauthier et al., 2015; Prodělalová et al., 2019), IAPV (Chen et al., 2014), and DWV (Fievet et al., 2006; Yue et al., 2006; de Miranda and Fries, 2008; Yañez et al., 2012a; Prodělalová et al., 2019) in semen, which first identified the potential for sexual transmission. Similarly, the occurrence of viruses in the spermatheca of mated queens such as DWV (Chen et al., 2006; de Miranda and Fries, 2008; Francis et al., 2013) and IAPV (Chen et al., 2014) suggests the potential for virus found in sperm to cause infection in the queen tissues; confirming the possibility for sexual transmission through artificial insemination (Yue et al., 2007; de Miranda and Fries, 2008). However, the question whether venereal transmission also occurs naturally remains unresolved. The detection of high titers of DWV in the endophalluses of drones sampled from drone congregation areas (Yañez et al., 2012a), where they can potentially mate with queens during nuptial flights, as well as in the mating signs collected from returning queens (Amiri et al., 2016), showed that there were no functional consequences of high DWV loads in reproductive drones for natural venereal virus transmission. Furthermore, high viral titers were detected in some of the endophallic remains that were left inside mating organs of returning mated queens by the last mating drone (Amiri et al., 2016), again showing that such high-titers were no hinder to successful mating. Similarly, high DWV titers were found in the spermathecae and in the sperm contained in these for several of the tested queens (Amiri et al., 2016). These results provide evidence that DWV can be transmitted through both artificial and natural mating, confirming the earlier indirect evidence from artificial insemination (Chen et al., 2006; Yue et al., 2006, 2007; de Miranda and Fries, 2008).

\section{Vertical Transmission}

For honey bees, vertical transmission involves the transfer of viruses from queens or drones (either directly through sperm or indirectly through prior venereal infection of the queen) to their offspring. Several studies reported detection correlated distribution of viruses in queens and their eggs, which implies vertical transmission. For instance, BQCV and DWV were detected in all analyzed queens $(N=10)$ and in all pools of 50 eggs from these queens (Chen et al., 2006). Other indirect evidence relevant for vertical transmission is the presence of viruses in the queen's reproductive organs. BQCV was detected in $70 \%$ of queen ovaries while DWV was detected in the ovaries of all analyzed queens (Chen et al., 2006). Francis et al. (2013) also showed the high prevalence of DWV in queen's ovaries with $80 \%$ $(N=86)$ testing DWV positive. Moreover, Fievet et al. (2006) showed that the ovaries were the organs with the highest DWV titers in their tested queens. de Miranda and Fries (2008) traced DWV through the entire venereal-vertical infection process, from artificial insemination through infection of the spermatheca and queen's ovaries to the resulting offspring, while Amiri et al. (2016) showed that ovaries can be infected with DWV after natural 
mating with DWV-positive drones and the virus can afterward be passed on to the eggs laid by these queens (Amiri et al., 2018). Not all the offspring from DWV-infected queens are DWV positive, nor do all DWV-infected queens also transmit vertically (Yue et al., 2007; de Miranda and Fries, 2008), so barriers to vertical transmission do exist, but in general terms the accumulated evidence indicates that DWV uses vertical transmission as a natural route for dissemination.

Regarding other viruses, the detection of CBPV (Chen et al., 2005, 2006; Blanchard et al., 2007; Ravoet et al., 2015b), IAPV (Chen et al., 2014), KBV (Chen et al., 2005; Shen et al., 2005a), SBV (Chen et al., 2005, 2006; Ravoet et al., 2015b), ABPV (Ravoet et al., 2015b), LSV (Ravoet et al., 2015b), Aphid lethal paralysis virus (ALPV, Ravoet et al., 2015b), and AmFV (Gauthier et al., 2015 ) in queens, their ovaries or in eggs, implies potential vertical transmission for these viruses as well. Additionally, the detection of BQCV, DWV, CBPV, KBV, and SBV in surface-sterilized eggs (Chen et al., 2006), strongly suggest transovarial transmission of these viruses, a pathway that involves the acquisition of the virus during oogenesis (however, see Amiri et al., 2018).

No information is available for vertical transmission of some less studied viruses, such as CWV, LSV, Moku virus (MV), BeeMLV, and/or ARV-1/BRV-1.

The present knowledge about which bee viruses are transmitted through various transmission routes is summarized in Table 1.

\section{Distribution of Bee Viruses in Other Apis Species}

Bee viruses are capable of infecting multiple host species and horizontal transmission seems to play a crucial role in the global viral distribution patterns in different species of social honey bees (Apis spp.), which share ecological habitats and geographic ranges, particularly in south-east Asia. The most prevalent viruses in Apis species are DWV and BQCV, which for historical reasons were first described in the European honey bee, A. mellifera (Chen and Siede, 2007; Zhang et al., 2012), but have since also been detected in other honey bee species. DWV has been detected in four honey bee species (A. mellifera, A. dorsata, A. florea and A. cerana) (Chantawannakul et al., 2006; Berényi et al., 2007; Sanpa and Chantawannakul, 2009; Kojima et al., 2011; Ai et al., 2012b; Li et al., 2012; Forsgren et al., 2015; Yañez et al., 2016). Nevertheless, DWV occurs less frequently in wild honey bees (i.e., A. florea and A. dorsata) than BQCV (Zhang et al., 2012; Mookhploy et al., 2015). BQCV and the AKI viruses are also multi-host pathogens that can infect all honey bee species, as well as numerous non-Apis species. Since BQCV can be transmitted via contaminated food sources such as honey and pollen, this may be a route of transmission for honey bees residing in close proximity by sharing food sources.

The presence of KBV in A. cerana was first shown in bees from India (Bailey and Woods, 1977) and later also in South Korea (Choe et al., 2012). IAPV has also been detected in A. cerana (Kojima et al., 2011; Ai et al., 2012b; Yañez et al., 2016).

Sacbrood virus has been detected in several Apis species (Allen and Ball, 1996). It is especially prominent and damaging
TABLE 1 | Routes of infection of viruses associated with honey bees. Overview of their horizontal and vertical transmission routes.

\begin{tabular}{|c|c|c|c|c|c|c|}
\hline \multirow[t]{3}{*}{ Virus } & \multicolumn{6}{|c|}{ Transmission } \\
\hline & \multicolumn{5}{|c|}{ Horizontal } & \multirow{2}{*}{$\begin{array}{c}\text { Vertical } \\
\text { Queen to } \\
\text { eggs }\end{array}$} \\
\hline & Oral* & Fecal & $\begin{array}{c}\text { Body } \\
\text { Contact }\end{array}$ & Venereal & $\begin{array}{l}\text { Vector- } \\
\text { mediated }\end{array}$ & \\
\hline IAPV & + & + & + & Ve.S. & $+(\mathrm{Vd})$ & + \\
\hline ABPV & + & + & BC.S & Ve.S. & $\begin{array}{l}\text { Vd.S., } \\
\text { Tm.S. }\end{array}$ & + \\
\hline $\mathrm{KBV}$ & + & + & BC.S & - & $+(V d)$ & + \\
\hline BQCV & + & + & $?$ & Ve.S. & - & + \\
\hline DWV & + & + & - & + & $\begin{array}{c}+(\mathrm{Vd}, \mathrm{Tm}, \\
\text { At.S.) }\end{array}$ & + \\
\hline SBV & + & - & - & Ve.S. & - & + \\
\hline SBPV & + & $?$ & $?$ & $?$ & $+(V d)$ & $?$ \\
\hline CWV & O.S. & $?$ & $?$ & $?$ & - & $?$ \\
\hline CBPV & + & + & + & - & Vd.S & + \\
\hline LSV & + & $?$ & $?$ & - & Vd.S. & + \\
\hline BeeMLV & $?$ & $?$ & $?$ & $?$ & Vd.S. & $?$ \\
\hline AmFV & + & $?$ & $?$ & Ve.S. & - & + \\
\hline ALPV & $?$ & $?$ & $?$ & $?$ & $?$ & + \\
\hline ARV-1/BRV-1 & $?$ & $?$ & $?$ & $?$ & Vd.S. & $?$ \\
\hline ARV-2/BRV-2 & $?$ & $?$ & $?$ & $?$ & Vd.S. & $?$ \\
\hline$A B V-1$ & $?$ & $?$ & $?$ & $?$ & $?$ & $?$ \\
\hline ABV-2 & $?$ & $?$ & $?$ & $?$ & $?$ & $?$ \\
\hline ArkBV & $?$ & $?$ & $?$ & $?$ & $?$ & $?$ \\
\hline BerkBPV & $?$ & $?$ & $?$ & $?$ & $?$ & $?$ \\
\hline BSRV & $?$ & $?$ & $?$ & - & $?$ & $?$ \\
\hline C/TSBV & + & $?$ & $?$ & $?$ & $?$ & $?$ \\
\hline$B V X$ & + & $?$ & $?$ & $?$ & $?$ & $?$ \\
\hline BVY & + & $?$ & $?$ & $?$ & $?$ & $?$ \\
\hline VTLV & $?$ & $?$ & $?$ & $?$ & Vd.S. & $?$ \\
\hline AIV & $?$ & $?$ & $?$ & $?$ & $?$ & $?$ \\
\hline MV & $?$ & $?$ & $?$ & $?$ & $?$ & $?$ \\
\hline VDV-2 & $?$ & $?$ & $?$ & $?$ & $?$ & $?$ \\
\hline VDV-3 & $?$ & $?$ & $?$ & $?$ & $?$ & $?$ \\
\hline VOV-1 & $?$ & $?$ & $?$ & $?$ & $?$ & $?$ \\
\hline AFV & $?$ & $?$ & $?$ & $?$ & $?$ & $?$ \\
\hline ANV & $?$ & $?$ & $?$ & $?$ & $?$ & $?$ \\
\hline ADV & $?$ & $?$ & $?$ & $?$ & $?$ & $?$ \\
\hline
\end{tabular}

ABPV, Acute bee paralysis virus; ABV-1, Apis bunyavirus-1; ABV-2, Apis bunyavirus-2; AmFV, Apis mellifera filamentous virus; ADV, Apis dicistrovirus; AIV, Apis iridescent virus (Bailey et al., 1979); ArkBV and BerkBPV, Arkansas bee virus and Berkeley bee virus (Bailey and Woods, 1974); AFV, Apis mellifera flavivirus; ANV, Apis Nora virus; ARV-1/BRV-1, Apis/Bee rhabdovirus-1; ARV-2/BRV-2, Apis/Bee rhabdovirus-2; BeeMLV, Bee Macula-like virus; BVX and BVY, Bee virus $X$ and $Y$ (Bailey et al., 1983a); BSRV, Big Sioux river virus (Runckel et al., 2011); BQCV, Black queen cell virus; IAPV, Israeli acute paralysis virus; C/TSBV, Chinese/Thai sacbrood virus; CWV, Cloudy wing virus; CBPV, Chronic bee paralysis virus; DW, Deformed wing virus; KBV, Kashmir bee virus; LSV, Lake Sinai virus; MV, Moku virus; SBV, Sacbrood virus; SBPV, Slow bee paralysis virus; VDV-2 and VDV-3, Varroa destructor virus-2 and -3 (Levin et al., 2016); VOV-1, Varroa orthomyxovirus1 (Levin et al., 2019); VTLV, Varroa Tymo-like virus (de Miranda et al., 2015). *, including trophallaxis, gut content and contaminated food; +, transmission confirmed; -, non-demonstrated transmission; ?, unknown; O.S., suggested oral transmission by presence in sealed brood; BC.S, suggested transmission by body contact; Ve.S., suggested venereal transmission by presence in semen and/or spermatheca; Vd, transmission confirmed by Varroa destructor; Vd.S., suggested vector-mediated transmission by Varroa destructor; Tm, transmission confirmed by Tropilaelaps mercedesae; Tm.S., suggested vector-mediated transmission by Tropilaelaps mercedesae; At.S., suggested vector-mediated transmission by Aethina tumida. 
in A. cerana (Shah and Shah, 1988; Grabensteiner et al., 2001; Sanpa and Chantawannakul, 2009; Yoo and Yoon, 2009; Choi et al., 2010; Kojima et al., 2011; Ai et al., 2012a; Forsgren et al., 2015; Yañez et al., 2016). Thai sacbrood virus (TSBV, also known as Chinese sacbrood virus) was the first virus discovered in A. cerana from Thailand in 1976 (Bailey and Collins, 1982). TSBV also caused the death of more than $90 \%$ of domesticated A. cerana populations in Kashmir (Abrol and Bhat, 1990), and was found in A. dorsata and A. florea in India (Allen and Ball, 1996).

Multiple viral infections in individual bees or whole colonies have been reported in both managed and feral colonies of Apis species. This emphasizes the importance of virus-virus and beevirus interactions (Takahashi et al., 2007; Choi et al., 2008; Sanpa and Chantawannakul, 2009; Ai et al., 2012a; Choe et al., 2012; Li et al., 2012; Ra et al., 2012; Reddy et al., 2013; Forsgren et al., 2015; Mookhploy et al., 2015).

During bee virus surveys in Asia, where both A. cerana and $A$. mellifera are cultivated, phylogenetic analysis of the capsid-protein gene of BQCV isolates from Thailand, China, South Korea, and Japan revealed a strong geographic clustering within Asia, distinct from South African and European isolates. No clustering were, however, observed according to the Apis host species that the isolates came from Mookhploy et al. (2015). BQCV isolated from Korea and Japan also showed similar levels of regional genetic variation, with high levels of similarity between isolates from the same country or continent (Kojima et al., 2011; Noh et al., 2013). That could be due to local transmission of viruses or spillover of BQCV from managed A. mellifera colonies to wild bees, as was the case for DWV spillover to local bumble bees (Fürst et al., 2014; Tehel et al., 2016). Another interesting point is that there appears to be no host-specific genetic adaptation by the virus when it is transmitted between bee species within the same geographic region (Fürst et al., 2014). It has been also suggested that in a twohost system, parasites may either evolve to be generalists, showing low levels of virulence, or specialists, displaying high virulence to each host species (Regoes et al., 2000). These studies highlight the complexity of bee virus disease ecology and transmission between their Apis and non-Apis hosts.

\section{New, Recently Discovered Bee Viruses}

Many new bee viruses have been discovered recently through high throughput sequencing (HTS) technologies (reviewed in Beaurepaire et al., 2020). Most of these have only been characterized taxonomically, through phylogenetic analyses of their genomic sequences, without any information about their biological properties, including, crucially, whether the bee they were found in is actually a true host or not. This includes recently described viruses such as Moku virus (Mordecai et al., 2016b); Apis Nora virus (ANV), Apis bunya virus-1,2 (ABV-1, ABV-2), Apis dicistrovirus (ADV) and Apis flavivirus (AFV) (Remnant et al., 2017), AmFV (Gauthier et al., 2015), Apis rhabdovirus1,2 (ARV-1,-2)/Bee rhabdovirus-1,2 (BRV-1,-2) (Levin et al., 2017; Remnant et al., 2017), as well as new viruses from the families Iflaviridae, Tymoviridae, Nudiviridae, and Parvoviridae (Schoonvaere et al., 2018) and new Tymo-, Seco-, Partiti-,
Noda-, Dicistro-, Circo-, Nege-, Sobemo-, and Toti-like viruses (Galbraith et al., 2018; Schoonvaere et al., 2018); and the many picorna-like viruses identified in Australian honey bees (Roberts et al., 2018). Investigating the biological properties of these genetically characterized viruses is the next logical challenge, since just their geographic origin or distribution is not sufficient to infer the putative danger these new viruses represent for honey bees.

\section{Transmission of Bee Viruses in Non-Apis Pollinators}

Most viruses that were first described in Apis sp. have also been detected in other bee species. Below we will give a short overview of the viruses detected in non-Apis species (for a more extensive review, we refer to Ravoet et al., 2014; Tehel et al., 2016; Gisder and Genersch, 2017).

Bumble bees are by far the most investigated non-Apis species with regard to viral infections and the presence of other pathogens (McMahon et al., 2015). Members of the DWV masters variants have been found in several Bombus sp. across different continents (Gisder and Genersch, 2017). Active replication of DWV in Bombus sp. has been confirmed in several Bombus species (Levitt et al., 2013; Fürst et al., 2014). Similarly for ABPV, IAPV and KBV infection in B. terrestris (Meeus et al., 2014), indicating that Bombus spp. are within the true host range of these viruses. Different viruses have different prevalences and titers in different bumble bee species (McMahon et al., 2015), which may reflect distinct susceptibilities, tolerances or transmission networks (Tehel et al., 2016; Figueroa et al., 2019). DWV infections have also been found in species of the genus Augochlora, Ceratina, Xylocopa, Andrena, Heriades, Osmia, Melipona, and Scaptotrigona (Singh et al., 2010; GuzmanNovoa et al., 2015; Tehel et al., 2016) and species belonging to Halictidae family (Evison et al., 2012; Levitt et al., 2013). Active DWV replication has been detected in Osmia cornuta. DWV titers in M. subnitida are similar to those found in honey bees. Both results suggest that DWV is capable of infecting and multiplying in at least Osmia spp. and Melipona spp. (Mazzei et al., 2014; de Souza et al., 2019). BQCV has been detected in several Bombus species as well as in Melipona and solitary bees of the genera Xylocopa, Osmia, Andrena and Heriades (Singh et al., 2010; Ravoet et al., 2014). Active replication of the virus has only been reported for Bombus spp. (Peng et al., 2011). The AKI virus complex has been detected in the genera Bombus, Augochlora, Andrena, Heriades, Xylocopa and Melipona, but active replication has only been shown in Bombus spp. (Singh et al., 2010; Levitt et al., 2013; Niu et al., 2016; Tehel et al., 2016; Alvarez et al., 2018) and bees from the Halictidae family (Levitt et al., 2013). So far infections with CBPV and SBPV have only been identified in Bombus sp., where active virus replication was verified only for SBPV (Niu et al., 2016).

Sacbrood virus was detected in Bombus, Andrena, Ceratina, and Xylocopa species (Singh et al., 2010; Levitt et al., 2013) and the Halictidae family (Levitt et al., 2013). Viruses of the LSV complex have been identified in Bombus, Osmia, and Andrena species, 
but virus replication has only been reported for Bombus sp. and Osmia sp. The species Halictus scabiosae, Halictus sexcinctus, and Halictus simplex were screened for viruses by Bigot et al. (2017), where the Halictus scabiosae Adlikon virus (HsAV) was described and identified as a virus closely related to LSV. ARV-1/BRV-1 was found in Bombus sp. (Levin et al., 2017). As apparent from this short overview, most of these viruses are detected in many different genera of bees. Therefore, it would be difficult to pinpoint the true host range of most viruses and our current knowledge is far from a clear understanding of the presence and replication of viruses in non-Apis and non-Bombus bee species. It is impossible to tell which bee species is the primary host, or even whether this question is relevant in the complicated context of bee virus transmission. Unraveling the directionality of virus transmission is therefore difficult from the current knowledge, based largely on natural surveys, but may benefit from systematic experimental approaches (e.g., Fürst et al., 2014; Meeus et al., 2014; Figueroa et al., 2019). That said, we will now break down the transmission routes into intra-species and inter-species transmission for non-Apis bee species.

\section{Inter-Species Virus Transmission}

Natural inter-species virus transmission can occur via several different routes (Figure 1). Oral-fecal transmission is most likely the main route of inter-species virus transmission. Several viruses such as $\mathrm{CBPV}, \mathrm{KBV}, \mathrm{DWV}, \mathrm{BQCV}$, and IAPV have been identified in the feces of honey bees (Hung, 2000; Chen et al., 2006; Ribière et al., 2007; Chen et al., 2014). Although no study to date has reported the presence of viruses in the feces of nonApis species, one could expect that virus particles are shed via the feces, similar to how this happens in honey bees. Several studies have directly identified the role of shared flowers in the transmission of a number of bee pathogens, including viruses (Singh et al., 2010; Graystock et al., 2015; Adler et al., 2018; Alger et al., 2019). Therefore, infected bees visiting flowers can contaminate the flower surface, nectar and pollen with virus particles they shed via their feces. Studies have identified the potential of indirect virus transmission via shared flowers (Singh et al., 2010; Bodden et al., 2019).

Analysis of the corbicular pollen from foraging honey bees showed the presence of SBV, BQCV and DWV in the pollen. DWV was also found in pollen collected by non-Apis bees. As infected pollen could be found on non-infected bees and vice versa (Singh et al., 2010), one can conclude that corbicular pollen is not primarily contaminated by the bee itself, e.g., through salivary excretions, but rather by previous visits from infected bees (Singh et al., 2010; Figueroa et al., 2019). The viability of the DWV present on the pollen has been demonstrated by injection into honey bees and Osmia spp. (Mazzei et al., 2014), although this does not of course mean a similar viability for oral infection. Oral transmission requires many orders of magnitude greater quantities of virus (de Miranda et al., 2013). DWV is naturally notoriously unstable outside the cell (de Miranda et al., 2013), and other pathogens are also known to lose viability rapidly on flower petals (Figueroa et al., 2019).

Apart from shared flowers, which is most likely the main route of inter-species transmission, there are other interactions between bee species that could promote the transmission of viruses between bee species. Robbing is one such interaction, where a bee steals stored resources from another nest, whether from the same or from a different species. Robbing is a wellknown phenomenon between honey bee colonies and occurs primarily during a dearth of floral resources (Kuszewska and Woyciechowski, 2014). Robbing of honey bee colonies by bumble bees (Genersch et al., 2006) and wasps has also been documented, but is more individual rather than systematic and usually toward the end of summer when both wasp and bumble bee colonies are in natural decline. Viruses can certainly be detected in honey (Milićević et al., 2018), so that robbing honey does expose robbing bees and wasps to potential infection (Genersch et al., 2006), but direct evidence for virus transmission through honey is so far absent, for honey bees or bumble bees.

Some social and solitary bees suffer from brood parasitism. This is when a different, parasitic bee species invades the nest of its host species and uses the host's resources to its own reproductive benefit (Lhomme and Hines, 2018). Such intrusion also involves exposure to potentially infectious viruses present in the host bees and brood or on the nest structures, enabling inter-species transmission from the nest of the host to the brood parasites.

Although rare, there are reports of bumble bee species reusing old nests (Taylor and Cameron, 2003). As viral particles can build up in the nest during the development, reusing an old nest will expose the new colony to these viruses. However, viral particles present in the old nest are exposed to environmental conditions (e.g., humidity and heat) and can deteriorate, losing their infectivity. The environmental stability of viruses found in honey bees seems to be highly dependent on the virus, where some viruses deteriorate faster compared to others (Chen et al., 2007; Dainat et al., 2011; Forsgren et al., 2017). Forsgren et al. (2017) showed that BQCV remains detectable up to 4 days in dead bees stored at $4^{\circ} \mathrm{C}$, whereas DWV degrades faster. One side note on these studies is that they do not assess the infectability of the virus. Because the environmental stability of the virus and the loss of its infectability likely differ between viruses present in a dead host and viruses that are outside their host, yet further research is still needed here.

The reuse of nesting sites is more common in solitary bees, which often re-occupy nesting sites used in previous years (Krunicì and Stanisavljevicì, 2006). As for bumble bees, old nest sites of solitary bees (i.e., hollow cavities in sand, stone, wood, or straw) can contain virus particles that were present on the pollen brought in by solitary bees the previous year. If these viruses are still contagious they could infect the adult female or the larvae of the next generation.

\section{Intra-Species Transmission}

The intra-specific transmission of viruses in non-Apis bees should also be highlighted. The very different lifestyles and social structures of non-Apis bee species will greatly affect how effectively, different bee viruses are transmitted.

Eusocial non-Apis species belong to the tribes Meliponini (stingless bees) and Bombini (bumble bees). Both tribes have a social structure similar to honey bees, with a single reproductive 


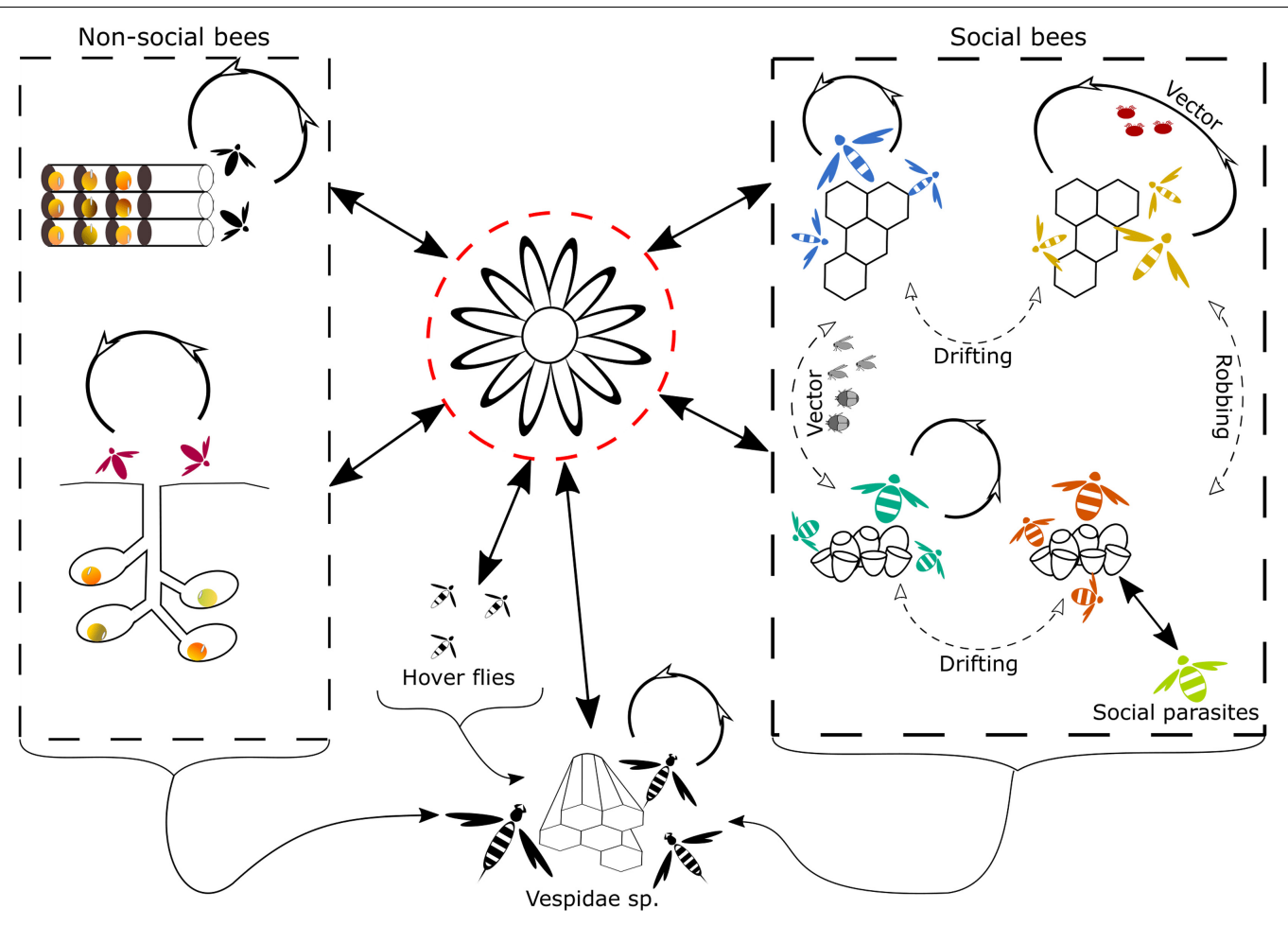

FIGURE 1 | Graphical representation of the natural routes of inter- and intra-species transmission of viruses found in Hymenoptera. Transmission routes that are more likely to occur are represented by solid arrows, transmission routes that are less likely or less frequently observed are represented by dotted arrows. The most likely route of inter-species transmission is through the use of shared flowers (Singh et al., 2010; Alger et al., 2019), depicted in the middle surrounded by a red dotted line. Inter- and intra-species transmission in non-social bees, depicted on the left side can occur through contact at nest aggregations or the reuse of virus-contaminated old nest cavities (Krunici and Stanisavljevici, 2006). In social bees, depicted on the right side, the main intra-species transmission route is likely, via intense contact in the nest. Social behavior such as trophallaxis and body contact could mediate transmission (Amiri et al., 2014, 2019; Chen et al., 2014; Coulon et al., 2018 and others, see main text). Further intra-species transmission can also occur via vectors, for honey bees this is a very important transmission route for several viruses, mediated by V. destructor (Santillán-Galicia et al., 2010; Möckel et al., 2011; Gisder et al., 2018; Posada-Florez et al., 2019; Ryabov et al., 2019 and others, see main text). Intra-and inter-species transmission via vectors, other than V. destructor [e.g., the small hive beetle, phorid flies (Eyer et al., 2009; Core et al., 2012; Menail et al., 2016)] are less frequent. Robbing and drifting are also two potential routes of inter- and intra-species transmission, respectively, described in social bees. Yet their role in virus transmission is likely to be minor compared to other transmission routes. Lastly, social parasitism creates a high contact between individuals from different species and hence is likely to facilitate virus transmission, in social bees. Inter-species transmission in Vespidae sp. can occur through feeding on infected Hymenoptera, or other insects that are infected with a virus or contain the virus on their exterior (Loope et al., 2019). Another potential transmission route for wasps is the use of shared contaminated flowers (Mordecai et al., 2016b). Intra-species transmission in social Vespidae sp. is also likely to occur via intense contact within the nest.

queen and non-reproductive worker bees attending the brood and foraging. A social nest structure creates a high contact between nest mates which facilitates virus transmission. Bees of the family Halictidae are widely distributed. This family displays a plasticity of social behaviors ranging from solitary to communal, semi-social and primitively eusocial (Danforth, 2002), allowing for different levels of horizontal transmission. Strictly solitary species on the other hand have very little contact with other individuals from the same species, apart from mating. Intraspecies transmission here is most likely via the use of shared flowers or potential contact in large nest aggregations.

Drifting is a term used for bees with faulty orientation and homing, when bees enter a non-natal colony from the same species. This phenomenon is well described for honey bees (Pfeiffer and Crailsheim, 1998), but it also occurs in other bee species, e.g., Halictus ligatus (Packer, 1986), Melipona scutellaris (Alves et al., 2009) and Bombus sp. (Lopez-Vaamonde et al.,
2004). Drifting exposes the intruding individual to the nest structures or pollen provisions of other individuals from the same species and may thus facilitate viral transmission.

\section{Vector-Mediated Transmission}

Another possible transmission route between non-Apis bees are parasitoids, parasites and commensals living in, on or with the host bee or its nest structures. Neither $V$. destructor, the highly potent vector of honey bee viruses in A. mellifera (Traynor et al., 2020) nor similar virus-transmitting mites parasitizing Apis bees in Asia (Forsgren et al., 2009, etc. see above in section "VectorMediated Transmission" in: Transmission of Viruses in Apis mellifera) parasitize non-Apis bees. However, non-Apis bees are host to a plethora of other parasites, ranging from ecto-parasites to parasitoids, that could potentially vector viruses. DWV has been identified in several species of parasitoid phorid flies, i.e., Megaselia scalaris and Apocephalus borealis, with evidence of 
replicating virus in the larvae of Megaselia scalaris (Core et al., 2012; Menail et al., 2016). A. borealis is a known parasitoid of bumble bees, which was also detected in honey bees. M. scalaris on the other hand is a broad host parasitoid, known to affect different insect species (Robinson, 1975; Mongiardino et al., 2013) and has also been suggested to be a parasitoid of Melipona colonies (Macieira et al., 1983). Even though DWV has been identified in these phorid flies, further research is still needed to establish the true potential of these species as an intraspecific and potentially inter-specific vector of bee viruses. The geographic expansion of the invasive SHB to temperate climatic zones means that it can now also encounter various bumble bee species, whose colonies it is able to invade (Hoffmann et al., 2008). Not least, it has been recently shown that SHBs can also complete an entire life cycle in association with nests of solitary bees Megachile rotundata (Gonthier et al., 2019). Since SHB is a replicative host or biological vector for DWV (Eyer et al., 2009), such invasion may result in the transmission of viruses among bee species.

\section{Transmission of Viruses in Non-bee Insects Hymenoptera}

Many species of the Vespidae family prey on bees and/or share nectar resources with Apoidea, this exposes them to bee-associated viruses. Several of these viruses have been detected in wasps of the Vespidae family. DWV has been reported in several species of the Vespula genus such as V. vulgaris, $V$. pensylvanica, V. crabro, V. velutina, and other Vespula spp. (Singh et al., 2010; Evison et al., 2012; Levitt et al., 2013; Forzan et al., 2017; Mazzei et al., 2018). Furthermore, DWV has also been detected in other genera of the Vespidae family such as Polistes spp. and Bembix spp. (Singh et al., 2010; Santamaria et al., 2018) the latter genus is mostly known to hunt flies (Evans, 2002), but is also described as a predator of stingless bees (Evans and O'Neill, 2007). Besides DWV other viruses have also been detected in wasp species, such as IAPV (Yañez et al., 2012b), Moku virus (Garigliany et al., 2017) ALPV, KBV, and BQCV (Mazzei et al., 2019; Yang et al., 2019). An RNAseq analysis of different tissues of Asian hornets, $V$. velutina, recently identified 18 virus species and added ABPV, BeeMLV and DWV-C to the list of bee associated viruses found in wasp species (Dalmon et al., 2019). Furthermore, the same study showed the presence of DWV, BQCV, and ABPV in tissues other than the gut, which suggests that these viruses cause a real infection in V. velutina. Similarly, the detection of virus replication of DWV, IAPV, KBV, and BQCV strongly suggests these viruses truly infect wasp species (Yañez et al., 2012b; Forzan et al., 2017; Mazzei et al., 2018, 2019).

Interestingly, a study in Hawaii by Loope et al. (2019) showed that the presence of $V$. destructor in A. mellifera has a cascade effect on the DWV variants found in Vespula pensylvanica. The arrival of $V$. destructor reduced the DWV variant diversity in honey bees as well as $V$. pensylvanica. These results further underline that predation of bees by wasps is a potential route of virus transmission. Furthermore, Mordecai et al. (2016b) showed that Moku virus is predominantly present in $V$. pensylvanica but is also found in honey bees and varroa in the same locations. Their data suggest that $V$. pensylvanica is likely the primary host of Moku virus, based on high viral loads and full genome recovery of the virus in the wasp. However, as they found the virus also in honey bees and $V$. destructor, it is also transmitted from wasps to bees and subsequently to varroa, the most likely route here is transmission via the use of shared flowers (Mordecai et al., 2016b).

The Moku virus, also highlights that for several viruses found in honey bees, the honey bees themselves may not be the primary host, yet they acquire the virus from other species. This has also been shown by de Souza et al. (2019), who found that DWV-C was more dominant in Melipona subnitida compared to A. mellifera in Brazilian colonies. Although the honey bee is often the focal host of studies, the detection and identification of honey bees as a potent host species for a virus does not directly imply that the honey bee is the primary host for this virus. Further research is still needed to untangle the role of different host species for most viruses found in honey bees.

The ants Camponotus vagus and Formica rufa feed on honeydew but also honey bee cadavers. Both species, when collected near apiaries, have been shown to carry CBPV which they could have acquired either through feeding on dead infected bees, or by sharing the same source of honeydew (Celle et al., 2008). Larvae and adult Lasius platythorax ants collected from honey bee colonies have been shown to carry ABPV, DWV-A, and DWV-B (Schläppi et al., 2020). Replicative strands of the CBPV and ABPV genomes were detected in C. vagus and in L. platythorax, respectively, suggesting possible viral replication and true host status for these ant and wasp species. However, as with $V$. destructor, such results should be interpreted with caution, since the virus (and its replication intermediates) may have come with the bee cadaver, rather than from the wasp/ant host tissues. Similarly, replicative strands of the DWV genome were detected in Myrmica rubra (Schläppi et al., 2019), an invasive species of ant in North America (Groden et al., 2005), and in the Argentine ant Linepithema humile (Sébastien et al., 2015), also one of the most widespread and abundant invasive ant species (Holway et al., 2002). Specific strains of LSV were detected in Messor ant species, which were thought to be genuine infections rather than the result of inter-species transmission (Bigot et al., 2017).

\section{Coleoptera}

The SHB, Aethina tumida, is a scavenger/parasite of honey bee colonies that was native in Africa, but has recently become invasive on several continents. Adult beetles enter honey bee and bumble bee colonies where they mate and reproduce. SHB feeds on the pollen, honey and honey bee brood and is therefore exposed to any virus found in these hive products (Neumann and Elzen, 2004). Additionally, the SHB can exploit trophallaxis and be fed directly by bees. Furthermore, replicative strands of the DWV genome have been detected in A. tumida (Eyer et al., 2009), although these can be either acquired passively through feeding or indicate active virus replication in SHB. BQCV, DWV, IAPV, $\mathrm{KBV}$, and SBV, have been detected in A. tumida as well (Levitt 
et al., 2013). Additionally, DWV has been detected in individuals of the Coccinellidae and Tenebrionidae families (Levitt et al., 2013). However, further research is still needed to confirm the host status of Coleoptera for these viruses.

\section{Diptera}

The adults of some species of hoverfly (Syrphidae, Diptera) are considered to be Batesian mimics of adult honey bees. They feed on flowers, effectively imitate honey bee behavior (Golding and Edmunds, 2000) and share many floral resources with bees as adults (Power and Stout, 2011). It has been shown that some species of the genus Eristalis carry BQCV, SBV, and DWV-B, most likely acquired through horizontal transmission (Bailes et al., 2018). Levitt et al. (2013) reported the presence of DWV in samples of the Calliphoridae and the Muscidae families of flies.

\section{Other Insects}

Levitt et al. (2013) collected a large number of insects in the proximity of apiaries and screened them for the presence of five bee-associated viruses. In addition to the detection of bee viruses in various species of Hymenoptera, Coleoptera, and Diptera (as mentioned above), BQCV, DWV, IAPV, KBV, and SBV were all also detected in species of Blattodea, Dermaptera, and Lepidoptera, while only DWV was detected in a specimen of Pentatomidae. None of these viruses were detected in specimens of Odonata or Orthoptera, although only very few specimens of these orders were analyzed.

\section{Other Arthropods}

Several bee-associated viruses, BQCV, DWV, IAPV, and SBV, were detected in Arachnids sampled near apiaries. As with other parasites, parasitoids and commensals, it is unclear if these viruses represent true infections (and thus host status) or were acquired passively through feeding on infected bees or contaminated material (Levitt et al., 2013).

\section{PART 2: ARTIFICIAL INFECTIONS}

This section deals with the deliberate, experimental infection of bees with controlled amounts of virus, using a variety of inoculation techniques, trying to mimic a natural transmission route. This requires a source of relatively pure virus and, ideally, uninfected experimental bees. The success of the infection procedure is tested either through molecular evidence of replication of the inoculated virus, or more commonly a significant quantitative increase in post-inoculation virus titer that can only be attributed to the inoculum. A number of negative control inoculations are therefore also required, to rule out alternative sources of infection or virus titer increase.

\section{Sources of Virus Inoculum}

The primary requirement for controlled inoculation is a source of relatively pure virus. There are two main approaches to achieving this: through the in vivo (bees) or in vitro (cell cultures) propagation of natural virus isolates (de Miranda et al., 2013; Genersch et al., 2013), or through reverse genetics, where the entire virus genome is transcribed synthetically from plasmid clones or PCR products and introduced into bees as full-length infectious RNA (Benjeddou et al., 2002; de Miranda et al., 2013; Lamp et al., 2016; Ryabov et al., 2019). Most studies on artificial inoculation of bee viruses thus far have been conducted with virus material propagated in vivo, in honey bee pupae, and enriched and purified through differential centrifugation (de Miranda et al., 2013). Because multiple virus infections are common in the bee colonies and most bee viruses have similar physico-chemical properties, making it impossible to separate them by differential centrifugation, these studies normally involved semi-pure virus inocula containing varying amounts of contaminating viruses (Bailey and Ball, 1991; Carrillo-Tripp et al., 2015; Remnant et al., 2019; Thaduri et al., 2019). Covert virus infections (virus present at very low levels) in either the propagating pupae, for preparing inoculum, or in the experimental bees can easily be co-amplified and interfere with the virus under study (Carrillo-Tripp et al., 2015; Remnant et al., 2019). Moreover, crude bee preparations also contain host cellular material that can independently or in synergy with either the inoculated or resident background viruses to influence the virus infection dynamics. An alternative approach would be to synthesize the virus of interest in vitro (Lamp et al., 2016; Ryabov et al., 2019; Seitz et al., 2019; Jin et al., 2020; Yang et al., 2020) thereby ensuring the highest level of purity. Both cell cultures and reverse genetics also allow virus to be produced that is free of contaminants, while reverse genetics also has the option of introducing specific genetic changes to the virus genome (Lamp et al., 2016; Ryabov et al., 2019; Jin et al., 2020). The combination of reverse genetics and cell culture propagation is particularly powerful for obtaining large amounts of pure infectious virus particles. However, despite persistent attempts during the last several decades, it was not until recently that cell culture systems and infection methods were optimized for honey bee virus infection and propagation (Genersch et al., 2013; CarrilloTripp et al., 2015) and full-length infectious plasmid clones of several honey bee viruses were developed (Yang et al., 2013; Lamp et al., 2016; Ryabov et al., 2019; Seitz et al., 2019). Recently, a molecular clone of CBPV was shown to cause typical clinical symptoms mimicking naturally CBPV-infected honey bees (Seitz et al., 2019). Similarly, SBV and DWV clones have been synthetized to express the enhanced green fluorescent protein (EGFP; Jin et al., 2020; Ryabov et al., 2020). Besides creating a clone that produces typical symptoms, it adds the advantage of a reporter gene for protein expression studies (Jin et al., 2020). One valid criticism of the reverse genetics approach is that it usually involves a single pure genetic clone, while viruses exist naturally as quasispecies - a collection of interrelated major variants, point mutants, recombinants and defective genomes (Dolan et al., 2018). Experiments with pure single genome viruses therefore lack the functional and genetic complexity of natural virus isolates. The obvious solution to this is to create a diverse set of infectious cDNA clones representing the genetic diversity of the original population (e.g., Ryabov et al., 2019).

Multiple positive and negative controls for all the steps of the inoculation process, from the manipulation of the individuals, incubation conditions, mode of inoculation, etc., are required 
to ensure that the infection is due to the target virus in the inoculum, and not due to contaminants in either the inoculum or the recipient host. The quality and quantity of the virus in the original inoculum as well as in the inoculated bees can be evaluated by qualitative and quantitative real-time PCR and by sequencing. The methods for virus propagation and virus infectivity assays have been described in detail in the Beebook (de Miranda et al., 2013). Here, we focus on summarizing the results of virus infectivity assays conducted during the last years.

Artificial infection experiments in honey bees primarily involve two forms of inoculation: by direct injection of micro volumes of virus into the honey bee using a fine needle, mimicking the vectored transmission by varroa, or by feeding, mimicking the oral-fecal transmission route. Very occasionally topical application is used, mimicking transmission by contact. Inoculation by injection allows absolute control over the amount of virus each bee receives, but not necessarily of the subsequent progression of the infection. This is because injection directly by-passes the main physical and physiological antiviral defenses, leaving the infection subject to only molecular controls. This is in contrast to oral inoculation, which often requires much higher amounts of virus (between $10^{6}$ and $10^{11}$ particles, depending on the virus; Bailey and Gibbs, 1964; Bailey and Ball, 1991; de Miranda et al., 2013) to initiate infection, due to these natural physical and physiological barriers, but whose subsequent progression is much more measured and predictable. The precise conditions for artificial inoculation vary greatly among viruses. Some of them have been studied widely while for others this information is largely unknown.

\section{Oral Inoculation and Injections $D W V$}

Oral inoculation of adult bees with DWV does not induce overt DWV infections, even when using large titers of the virus ( $10^{8}$ genome equivalents), and the virus was restricted to the abdominal organs (Möckel et al., 2011). Artificial oral inoculation of DWV seems to be rather ineffective (Iqbal and Mueller, 2007), much of which can be attributed to the extreme instability of DWV in isolation (de Miranda et al., 2013). However, when feeding 2 days-old larvae with $2 \mu \mathrm{l}$ of serial dilutions of DWV, Khongphinitbunjong et al. (2015) observed significant higher viral titers in the resulting adults than in sucrose-fed controls, suggesting that both the developmental stage used for oral infection and the virus quantity were significant for establishing infection. Similar results were obtained by Thaduri et al. (2019) for oral inoculation of larvae with a single dose of freshly prepared crude DWV extracts containing $10^{8}-10^{9}$ DWV genome equivalents, although the majority of this would have been unpackaged cytoplasmic RNA and only a fraction from virus particles. The results for adult bees were equivocal due to the high background levels of DWV in newly emerged adult bees (Thaduri et al., 2019). Artificially reared newly hatched larvae orally inoculated with high doses of DWV (about $10^{10}$ virus genome equivalents) established high levels of DWV infection (Ryabov et al., 2016). Sequential experimental oral infections with DWV and Nosema ceranae in 2 days old workers resulted in lower DWV loads when N. ceranae was inoculated before
DWV, suggesting competitive interference between pathogens (Doublet et al., 2015).

Overt DWV infections could only be obtained through injecting the virus into young pupae (Möckel et al., 2011; Natsopoulou et al., 2017; Dubois et al., 2020; Yañez et al., 2020), even with as little as 80 virus particles, but never through feeding (Möckel et al., 2011). Injection has been used frequently to mimic natural inoculation by varroa while feeding on nymphs or adult bees. Worker pupae at the white eye stage (12-13 days old) microinjected with $10^{6}$ copies of DWV exhibited virus replication and significant immune-gene expression modulations 5 days post injection (Ryabov et al., 2016), and injection of $10^{7}$ copies of either clone-derived DWV isolates or wild DWV isolates reached about $10^{10}$ to $10^{11}$ genome copies per bee after only $24 \mathrm{~h}$ postinjection (Ryabov et al., 2019). Similar results were obtained by Yañez et al. (2020) when serially injecting DWV into pink-eye pupae. When young adults were injected with $10^{4}$ to $10^{6}$ copies of DWV into the thorax or abdomen no acute mortality was observed but the bees' lifespan decreased and flight behavior was affected (Mazzei et al., 2016; Bigot et al., 2017; Coulon et al., 2020). Both Natsopoulou et al. (2017) and Dubois et al. (2020) showed that DWV-A and DWV-B were equally capable of causing DWV symptoms, after injecting white-eye pupae and letting the pupae complete development in vitro. Mortality was significantly higher for adult honey bees injected with $10^{7}$ copies of DWV-B compared to bees injected with the same amount of DWV-A (McMahon et al., 2016). Gisder et al. (2018) showed that a DWV-B dominant isolate from mites changed genetic character to a DWV-A dominant derived isolate after a single passage in bee pupae, most likely through a simple quantitative shift in the relative levels of DWV-A and DWV$\mathrm{B}$ genomes after passaging. The original DWV-B dominant isolate was more virulent than the evolved DWV-A dominant isolate when considering pupal mortality and adult bee cognitive behavior, but not for adult bee mortality. The elevated virulence of the DWV-B dominant isolate could be attributed to more efficient replication in pupae and wider dissemination in adult bee neurological tissues. The consensus sequences of matching source and passaged isolates with different virulence properties clustered differently with either DWV-A or DWV-B, depending on which region of the genome was analyzed, which allowed the elevated virulence to be mapped to the DWV-B RNA-dependent RNA polymerase (RdRp) region of the DWV genome (Gisder et al., 2018). Such differential phylogenetic affiliation across the DWV genome is most easily explained by a significant presence of recombinant viruses in the quasispecies, enough to change the genetic character of the consensus sequence of the whole isolate (Dolan et al., 2018). Such DWV-A/DWV-B recombinants are readily generated naturally in mixed infections (Moore et al., 2011; Zioni et al., 2011; Ryabov et al., 2014, 2019; Cornman, 2017; Dalmon et al., 2017) and have been used to map other differential traits of DWV-A and DWV-B as well (Moore et al., 2011; Ryabov et al., 2014, 2019).

\section{$S B V$}

Bailey et al. (1981) preferred injection to pupae up to $24 \mathrm{~h}$ old rather than injection in adult bees when infecting bees with 
BQCV, SBV, and SBPV. Early reports indicate that SBV extracted from larval or adult tissues (by grinding them in a 4:1 mixture of water and carbon tetrachloride followed by clarifying the extracts by centrifugation) were infectious to A. mellifera. Mature adult worker bees were infected by injection; newly emerged adult workers and larvae were infected by feeding (Bailey, 1969). Extrapolation from Bailey's data indicates that about $10^{7}-10^{8}$ viral particles fed to larvae resulted in above 90\% mortality (Bailey, 1969; Bailey and Fernando, 1972). Electron microscope counts of the of virus particles from extracts of the heads of drones 5 days after injection indicated that about $7 \times 10^{11}$ particles per dronehead, at least 100 times the number in an infected adult worker bee head (Bailey, 1969). Liu et al. (2010) reported that second instar A. cerana larva were fed with $5 \mu \mathrm{l} \mathrm{SBV}$ (Chinese SBV) solution or PBS $\left(7.8 \times 10^{5}\right.$ genome copies/ $\left.\mu \mathrm{l}\right)$. Over $90 \%$ larval mortality was achieved by $96 \mathrm{~h}$ post infection. When comparing transmission for both DWV and SBV, Ryabov et al. (2016) used an inoculum of a mixture of approximately $10^{10}$ SBV and $10^{10}$ DWV genome equivalents for young larvae (oral infection), and $10^{6} \mathrm{SBV}$ and $10^{6} \mathrm{DWV}$ genome equivalents for pupae (injection).

\section{$B Q C V$}

Oral inoculation was successfully used to inoculate pre-pupa (7 days) or 2 days old workers (respectively, $1.4 \times 10^{7} \mathrm{BQCV}$ genome equivalents per larva and $1.4 \times 10^{9}$ genome equivalents per bee) to look for interactions between pathogens (BQCV and $N$. ceranae) and between the virus and pesticides (Doublet et al., 2015). Dose-dependent inoculation assays showed that only the high titers of BQCV $\left(1.4 \times 10^{9}\right)$ caused higher mortalities of the larvae but no impact on adult worker survival was observed (Doublet et al., 2015).

\section{ABPV, IAPV, KBV}

Bailey et al. (1963) challenged adult honey bees with ABPV in three different ways: by feeding, spraying, and artificial injection of an ABPV suspension. The $\mathrm{LD}_{50}$ (number of ABPV particles per bee that would have killed half of the bees in a group after 6 days) was equivalent to about $10^{2}$ virus particles per bee when preparations were injected into the haemocoel compared to more than $10^{11}$ virus particles per bee for feeding and $10^{8}$ to $10^{9}$ particles per bee for spraying, illustrating the high virulence of ABPV upon injection.

Boncristiani et al. (2013) described that in vitro injection of honey bee pupae with $10^{4}$ viral genome equivalents of an IAPVenriched extract resulted in symptomatic infection.

Oral infections with IAPV can be achieved by feeding IAPVsucrose solution to honey bees in cage experiments and in honey bee colonies (Maori et al., 2007, 2009; Singh et al., 2010). Approximately 5-7 $\times 10^{9}$ IAPV genome equivalents in $30 \mathrm{ml}$ sucrose were used to obtain colony infections) (Singh et al., 2010). IAPV-enriched sucrose solutions caused high mortality of recently emerged adult bees (concentrations above $10^{8}$ genomic copies per microliter, NC, unpublished).

An inoculum containing a mixture of viruses, enriched for SBV and IAPV with low levels of BQCV and DWV was able to produce high levels of mortality within 3 days of oral infection in newly emerged honey bees. Further investigation concluded that the bees died from the extremely high titers of IAPV, and not from other viruses (Carrillo-Tripp et al., 2016; Dolezal et al., 2016).

\section{$S B P V$}

Adult bees injected with preparations of SBPV and antisera to neutralize all the other known bee viruses died after about 12 days at 30 or $35^{\circ} \mathrm{C}$. They suffer a paralysis of the legs a few days before death and contained about $10^{12}$ viral particles (Bailey and Woods, 1974).

\section{CBPV}

Blanchard et al. (2007) reported infection of adult bees after topical application of $1.8 \times 10^{8} \mathrm{CBPV}$ genome equivalents on the thorax of the bees. Trembling and weakening symptoms were observed 7-8 days post-application and all bees died 8-9 days post-contact (Blanchard et al., 2007). Queens can be infected by topical application of CBPV or following their exposure to CBPV-infected adults. The disease's symptoms include trembling of the legs, spread and disjunct wings and sometimes bloated abdomens (Amiri et al., 2014). Coulon et al. (2018) set up contact transmission experiments, mimicking the natural transmission route in the hive that avoids the stress of shaving and topical application. Tagged bees previously injected (4 days earlier) into the thorax with $4 \times 10^{4} \mathrm{CBPV}$ genome equivalents were reared in the same cage with 9-day-old bees. Many of the bees that received the inoculum died after 1-3 days, but $69 \%$ of the bees that were in contact with them were still alive after 10 days despite the high titers of CBPV (about $10^{8}$ CBPV genome equivalents, Coulon et al., 2018).

\section{Infection by Mites}

After 6 days the larvae that was fed with larval food provided by nurse bees, which was naturally infected with DWV, showed lower DWV titers (about $10^{6}$ genome equivalents/larvae) than larvae exposed to $V$. destructor (Ryabov et al., 2014). Pupae artificially infested with one mite resulted in higher prevalence of DWV in adults than adults from non-infested pupae and DWV titers reached up to $10^{10}$ genome equivalents per bee even if the distribution of DWV titers across bees were highly varied

Santillán-Galicia et al. (2014) investigated the ability of $V$. destructor to transmit SBPV. A. mellifera and mites were fed on SBPV-infected pupae for either 5 or 10 days. Using Probit analysis, they estimated doses necessary to cause $50 \%\left(\mathrm{LD}_{50}\right)$ and 99\% (LD99) mortality in bees was 362 and 2266 virus particles, respectively. A time course of SBPV replication in pupae showed that the virus was first detected $42 \mathrm{~h}$ after injection. No significant differences were found in the overall proportion of pupae that became infected when mites were introduced over a period of 5 or 10 days, irrespective of the season (July or September). The proportion of pupae infected with SBPV declined significantly with each mite transfer over time, with the majority of pupae becoming infected after the first few mite transfers. These experiments suggest that transmission of SBPV does occur during mite feeding. Furthermore, they conclude that because SBPV is highly virulent as it kills the bees before any dramatic increase in virus titer. This results explains why low SBPV titers exist in honey bee colonies even in the presence of V. destructor (Santillán-Galicia et al., 2014). 


\section{Cross-Infection Between Bee Species Apis Species}

Only a few studies have been conducted on artificially crossinfection of bee viruses between different Apis species, mostly due to the lack of in vitro brood rearing techniques for Apis species other than A. mellifera. Kashmir bee virus was originally found in Eastern honey bees, A. cerana in Kashmir (Bailey and Woods, 1977) and later found in A. mellifera in Australia (Bailey et al., 1979). Experimental work has shown that the virus could multiply very effectively in $A$. mellifera pupae. Inoculation with $1 \times 10^{-8}$ ng of purified virus was sufficient to cause infection in some pupae, and at doses of $1 \times 10^{-5} \mathrm{ng}$ of purified virus every inoculated individual became infected. Virus multiplication occurred in cytoplasmic membrane-bound vesicles and caused significant changes in the hemolymph osmolality of infected pupae (Dall, 1987). Bailey also found that infected A. mellifera adult bees died within 3 days after either injecting or rubbing KBV on their bodies (Bailey et al., 1981).

Chinese sacbrood virus (CSBV) originating from A. cerana could readily establish SBV infections in A. mellifera larvae and adults, through both natural and artificial infection (Gong et al., 2016; Sun et al., 2017). Although CSBV was shown to replicate in A. mellifera adult bees and larvae, no obvious signs of sacbrood disease was observed (Gong et al., 2016).

\section{Bombus Species}

Many studies have shown that viruses first identified in honey bees could also be detected in Bombus and other pollinator species (e.g., Singh et al., 2010; Fürst et al., 2014; Gusachenko et al., 2019; see Gisder and Genersch, 2017 for an extensive overview). Several studies also report the active replication of these viruses in Bombus spp., indicating that these non-Apis bee species are also true hosts for these viruses. However, merely establishing that a virus can replicate in a bee species says nothing about either the pathology or the intra-species transmission of the virus. This additional biological information is crucial for evaluating the ecological consequences of virus prevalence in non-Apis pollinators. Establishing the pathology of bee viruses in non-Apis pollinators is often difficult, since the contact history of wild-caught bees is not known. Moreover, wild specimens often have multiple infections with several viruses and/or other pathogens have not yet been developed. Artificial infections allow the study of a certain virus in a controlled environment. They also provide insight on the transmission ability of viruses between species. Artificial (cross-species) infections can be performed either by direct injection of the virus in the bee, or through oral administration. In the following sections, we provide a short overview on the application of different infection techniques to look at cross species infection potential.

\section{Micro-Injection}

The micro-injection procedure used in bumble bees is similar to that used in honey bees. Firstly, bees are anaesthetized by putting them in the freezer for 10-20 min, subsequently bees are injected using a micro-capillary in the soft tissue between the first pair of sternites (Niu et al., 2016). Niu et al. (2014) showed that injection with as low as 20 virus particles of IAPV originating from honey bees results in infection in B. terrestris. Similarly, Wang et al. (2017) showed that injection of 500 virus particles of IAPV from honey bees results in an acute infection inducing rapid mortality in $B$. terrestris. The injection of SBPV particles, on the other hand, has a much less lethal effect on $B$. terrestris. Niu et al. (2016) showed that injecting up to 200,000 virus particles resulted in a moderately increased mortality compared to the control. Interestingly, both IAPV and SBPV inocula originating from white eyed honey bee pupae, reach a similar amount of viral genome copies in the bumble bee, yet IAPV appears much more lethal compared to SBPV (Niu et al., 2016). While the presence of DWV is documented in field samples of several Bombus species, published experimental work is still scarce. Graystock et al. (2015) showed that injections of DWV in B. terrestris result in an infection and lead to $50 \%$ mortality 10 days after injection.

Other than bumble bees, Osmia sp. have been used to test cross-species infectivity of DWV through injection. Mazzei et al. (2014) injected O. cornuta with extracts DWV infected honey bees. The bees were injected into the thorax, and later replicating DWV could be detected in the abdomen of the infected bees but not in their heads.

\section{Feeding}

Feeding virus particles to bee species other than honey bees, more closely resembles the natural transmission process, as vectors injecting virus are not described for non-Apis bees. In nature cross-species infection most likely occur due to feeding on flowers contaminated with fecal matter containing virus particles (vide supra for transmission pathways).

Establishing an infection via feeding requires much more viral particles compared to injection, as not all administered virus is able to penetrate the gut tissue and enter the haemocoel. Meeus et al. (2014) reported successful oral infection of B. terrestris with KBV and IAPV using $1 \times 10^{7}$ and $0.5 \times 10^{7}$ virus particles, respectively. Similar orders of magnitude were reported for oral infection of $B$. terrestris with IAPV in other studies (Piot et al., 2015; Wang et al., 2019). Both feeding and injection of IAPV highly increase mortality of $B$. terrestris, yet injection is far more lethal compared to feeding (Wang et al., 2019). Similarly, feeding bumble bees with DWV particles is less efficient at triggering an infection compared to injection. B. terrestris fed with $1 \times 10^{9}$ of DWV particles show a significant infection in less than half of the individuals (Fürst et al., 2014). However, compared to honey bees, bumble bees can be housed alone without an increased mortality, when they have access to ad libitum sugar water.

Schläppi et al. (2020) reported oral transmission of ABPV to the black garden ant Lasius niger when feeding on highly infected honey bee pupae $\left(2 \times 10^{11}\right.$ virus particles $)$, which led to symptoms at colony (fewer emerging workers) and individual level (impaired locomotion and movement speed).

\section{Serial Transmission of Viruses in Honey Bees}

Historically, starting with the work of Louis Pasteur on rabies in the 19th century, serial passage of viruses in alternative hosts has been used for attenuating their virulence, in order to develop lowvirulence virus strains for use as live vaccines. The principle is 
that after the serial passage of a virus to another host species, a loss of virulence is experienced when inoculated again into the original host as the virus becomes adapted to the alternative host and less to the original host. However, serial passaging has also been used to select strains with increased virulence (e.g., HIV-2 in baboons, Locher et al., 2003) and as an experimental technique to study genetic adaptation in virus populations resulting in new viral population-level traits, such as the adaptation to new hosts.

Serial passaging of viruses from honey bees has thus far largely involved in vivo serial passaging in pupae and adult bees. This is mostly because immortal honey bee cell lines, a logical pristine environment for pure virus propagation, have not been available until recently (see the section "Cell Line in Honey Bees"). Serial passaging of bee viruses was initially used to identify the infectious agent associated with different disease symptoms in honey bees, most commonly paralysis, and subsequently also to maintain infective virus stocks for experimentation and raising diagnostic antisera. This work started in 1945 with single passages of extracts from paralytic bees (Burnside, 1945) and was developed more thoroughly during the 1960s-1970s, leading to the discovery and initial characterization of the most common and important bee viruses we know today (Bailey and Ball, 1991). For instance, in Bailey et al. (1963), stocks of ABPV and CBPV were maintained by serially injecting those viruses in adult bees. In the case of ABPV, the virus infectivity has been maintained by serial transmission for over two years. While CBPV has been maintained in a similar way for several months.

As mentioned above, serial passaging can be used to either decrease or increase virulence. Mussen and Furgala (1977) compared the virulence of several SBV extracts, including one obtained from symptomatic larvae and another from SBV serially transmitted through adult bees. Both extracts were then inoculated by injection into 1-day-old adult bees, with higher mortality observed with the extracts from adult bees $(100 \%$ mortality at 14 days after inoculation for adult-derived SBV, compared to $75 \%$ from symptomatic larvae). Similar experiments have recently also been conducted with the two master variants of DWV, comparing the relative virulence in honey bee pupae of DWV-A, the original honey bee specific strain (Lanzi et al., 2006; Posada-Florez et al., 2019), and DWV-B, a strain adapted to and capable of replicating in the parasitic mite and virus vector $V$. destructor (Ongus et al., 2004; Ryabov et al., 2019). In one study, no differences were observed in virus titers, development of symptoms or mortality between bees infected by DWV-A and DWV-B separately or infected by the mixture of both, through a single passage in white-eyed pupae (Tehel et al., 2019). In a different study, a single passage in pupae of a DWV isolate from a crippled bee significantly attenuated its virulence when injected into pupae (mortality) and in adult bees (neurotropism and cognitive ability), with attendant genetic changes in the virus linking higher virulence to sequence signatures from the DWV-B genotype, particularly the RNA-dependent RNA polymerase region (Gisder et al., 2018). As discussed above, this change in virulence could also be due to the presence of recombinants in a mixed infection. Virulence attenuation has also been demonstrated for varroa-mediated serial transmission, with reduced pupal DWV-A titers in pupae after just three varroa-mediated passages (Posada-Florez et al., 2019). These experiments demonstrate that artificial injection is useful for the transmission and propagation of viruses but may not reflect the natural interactions between each component within the three-way interactions between DWV, varroa and honey bees.

Serial passages were also used to evaluate viral species interaction during co-infection of the same host (Ryabov et al., 2016; Remnant et al., 2019). Virus isolates propagated in vivo in natural pupae inevitably include other common co-purifying viruses, such as SBV and BQCV, especially when propagating DWV (de Miranda et al., 2013) due to its innate instability in isolation (Lanzi et al., 2006). This will naturally also affect the replication and virulence characteristics associated with the propagated inoculum. From the first passages onward, DWVA was outcompeted by SBV and BQCV (Remnant et al., 2019) both of which replicate very efficiently upon injection (Bailey and Ball, 1991). These unique virus-specific differences revealed by competition between co-replicating viruses are also reflected in both common and virus-specific host molecular responses to co-infection with competing viruses (Ryabov et al., 2016).

Serial transmissions have also been used to test different transmission routes. For instance, Bailey and Gibbs (1964) tested the infectivity of ABPV through serial passages of bee feces. A hundred bees were each fed with $10^{6}$ ABPV particles. After 1 week, fifty bees were fed with syrup containing feces from the first group. The subsequent week, a serial transmission continued using another fifty bees fed with the feces from the second bee group. Those third group bees showed no symptoms of ABPV, nor was there any increase of virus or sign of disease during two further serial transfers. From these results, the author speculates that "when bees ingest feces while cleaning the hive, they become infected, but will be unlikely to receive enough virus to become acutely paralyzed."

Serial passages have been also used to elucidate the behavior of viral quasispecies during and after transmission. Yañez et al. (2020) followed the changes in the DWV-A quasispecies shape upon serial injection into honey bee pupae. The results suggested that DWV-A quasispecies undergoes a rapid, extensive and random expansion of its sequence space, followed by very strong negative selection toward a uniform, common shape by the time the pupae have completed their development, with no particular signature between symptomatic and asymptomatic adults.

Serial passages of viruses have been a useful tool to preserve the viability of virus and to understand the different routes of transmission during the early virology research on the honey bees. In recent years, a few studies used this technique to characterize the complex interactions between co-infecting viruses, $V$. destructor and the honey bee host.

\section{Cell Line in Honey Bees}

Following the initial attempts of creating in vitro insect cell cultures, the first primary cell line of continuously dividing insect cells was achieved in the 1960s (Grace, 1962), and since then, the field has grown to routinely cultivate primary cells and now immortalized or permanent insect cell lines (Lynn, 1999; van Oers and Lynn, 2010). According to the ExPASY Cellosaurus, thus far, around 1000 insect-derived cell lines have 
been established from several different tissue sources of many insect species, majority derived from the families Lepidopteran, Dipteran and Hemipteran (Lynn, 1999). Although there has been less success in the family Hymenoptera (wasps, ants, and bees) (Lynn, 2001), recent attempts have led to the first honey bee immortal cell line, AmE-711 (Goblirsch et al., 2013).

Honey bee primary cell cultures grow relatively slowly compared to other insect or animal cell cultures, regardless of the tissues used to initiate the cell culture (Genersch et al., 2013). Thus far, many attempts have resulted in several honey bee cell culture methods. These methods are highly varied as they use different target tissues, growth media and isolation methods (Bergem et al., 2006; Hunter, 2010; Ju and Ghil, 2015). Honey bee primary cell cultures have been established using different life stages from egg to adult bees and various isolated tissues including neural cells, antennae, fat body, hemocyte, and embryos (Kreissl and Bicker, 1992; Gascuel et al., 1994; Goldberg et al., 1999; Sorescu et al., 2003; Barbara et al., 2008; Ju and Ghil, 2015). Even transfection using human c-myc proto-oncogene into embryonic honey bee cells has generated a cell culture that remained viable for periods up to 8 months (Kitagishi et al., 2011). This cell line was considered as "of honey bee character" despite the expression of a central transcription factor being of human origin which is known to change the entire cellular program by un-regulating the expression of many genes (Nasi et al., 2001; Adhikary and Eilers, 2005). A major breakthrough in the development of a stable honey bee cell line came from the use of honey bee embryonic tissue (Goblirsch et al., 2013; Ju and Ghil, 2015), however, this and likely other primary honey bee cell cultures are plagued with persistent DWV infection, a condition afflicting honey bees worldwide (Martin and Brettell, 2019).

Insect-derived cell cultures have advanced our understanding of insect physiology, development biology, pathology, and molecular biology (Lynn, 1999; van Oers and Lynn, 2010). With their genetic uniformity, they are now used by scientists as a convenient tool to eliminate environmental variables with more consistent results that are impossible to control when working at the organismal or colony levels (Hunter et al., 2003; van Oers and Lynn, 2010). Cell cultures are desirable for detection, identification and isolation of many viruses and intracellular parasites in animals (Leland and Ginocchio, 2007; Hematian et al., 2016). They are especially valuable for rapid characterization of virus-virus, virus-host cellular interactions and their impact on cell survival, which could be commercially important (Carrillo-Tripp et al., 2015). That said, isolation of viruses from naturally infected bees and pupae, or artificially infected individuals in the laboratory (de Miranda et al., 2013), is still the preferred route for virus characterization studies because it is well known that immortalized cell cultures don't reflect the true evolutionary pressure presented to a virus cultivated in situ or in vivo. Thus far, honey bee virus studies have provided valuable information on the response of hosts to viruses at the population and physiological levels but immortalized driven honey bee cell lines will provide a stable supply of material to a nascent field of honey bee cellular virology (de Miranda et al., 2013; Genersch et al., 2013; Martin and Brettell, 2019). It will also lead to better understanding of honey bee antiviral defense mechanisms (Carrillo-Tripp et al., 2016). Recently, primary cell cultures derived from of both Asian and European honey bees embryonic tissues were used to investigated cellular responses to virus infection (Goblirsch et al., 2013; Xia et al., 2014; Ju and Ghil, 2015). A monolayer of the primary cell culture from embryonic tissues of A. cerana was used to study early infection process of CSBV during replication (Xia et al., 2014). The results from this study suggest that after viral adsorption and entry into the host cell, CSBV replicated and assembled progeny virions in the cytoplasm until $48 \mathrm{hpi}$, after which CSBV particles might be released from the host cell by lysis. An investigation of viral co-infection in the immortal cell culture from embryonic tissues of A. mellifera (AmE-711) revealed a similar virus dynamic as individual honey bee (Carrillo-Tripp et al., 2016). These results indicated that different mechanisms of virus-host interaction affect virus infection dynamics, including virus-virus interactions, superinfections, specific virus saturation limits in cells and virus specialization for different cell types (Carrillo-Tripp et al., 2016).

\section{CONCLUSION}

Although much is known about both the natural transmission routes and the artificial propagation of bee and bee-related viruses, much more still needs to be clarified. Most of our knowledge about bee virus transmission and infection has been derived from the most common honey bee viruses, i.e., those that also cause disease. The challenge is to elucidate the infection and transmission strategies of the much larger number of apparently non-pathogenic newly discovered viruses, as well as their biological and ecological importance to their hosts. Many of them will probably also use the most common transmission routes identified for the disease-causing viruses. The developmental stage and tissues targeted by these viruses will be important for both their transmission strategy and their effects on the host. Mechanical and biological virus vectors can breach the anatomical and physiological host barriers to virus transmission, with potentially drastic consequences for host health, virus virulence evolution, and applied vector-virus virulence management (Traynor et al., 2020). Also important in virus transmission, as recently reported by Wang et al. (2020) using a metabolomics-based approach, is the occurrence of diametrically opposite changes during virus infection of cells of different species origin, and we believe this phenomenon is possibly related to the type of infection (acute or persistent) that is triggered by the virus. Indeed Santos et al. (2019) and Wang et al. (2019) reported that virions/virus in insect species of three different orders (Lepidoptera, Hymenoptera, and Orthoptera) did not trigger pathogenic infections, while in Dipteran cells there were strong toxic effects (Wang et al., 2020), which can impact transmission among species in nature when sharing food resources. Indeed, Piot et al. (2019) demonstrated the impact of food hot spots on pathogens transmission within altered flower-networks that could negatively impact hosts experiencing an increased exposure. Finally, techniques revised here as inoculation methods, virus serial passaging and cell culture are 
all important tools for understanding virus quasispecies behavior, transmission, pathogenicity and virulence or its attenuation in different host bee species.

\section{AUTHOR CONTRIBUTIONS}

$\mathrm{OY}, \mathrm{AD}$, and $\mathrm{NC}$ conceptualized the study. OY, NP, AD, JM, DP, and NC investigated the study. OY, NP, AD, and NC contributed to methodology. OY, NP, AD, JM, PC, DP, EA, GS, DS, and NC wrote the original draft. OY, NP, AD, JM, PC, DP, EA, GS, and NC reviewed and edited the manuscript. OY, NP, AD, JM, PC, DP, EA, GS, DS, and NC approved the final version of manuscript to be published.

\section{REFERENCES}

Abrol, D. P., and Bhat, A. A. (1990). Studies on 'Thai sac brood virus' affecting indigenous honeybee Apis cerana indica Fab. colonies - Prospects and future strategies - I. J. Anim. Morphol. Physiol. 37, 101-108.

Adhikary, S., and Eilers, M. (2005). Transcriptional regulation and transformation by Myc proteins. Nat. Rev. Mol. Cell Biol. 6, 635-645. doi: 10.1038/nrm1703

Adler, L. S., Michaud, K. M., Ellner, S. P., McArt, S. H., Stevenson, P. C., and Irwin, R. E. (2018). Disease where you dine: plant species and floral traits associated with pathogen transmission in bumble bees. Ecology 99, 2535-2545. doi: $10.1002 /$ ecy.2503

Ai, H., Yan, X., and Han, R. (2012a). Complete genome sequence of a Chinese isolate of the Israel acute paralysis virus. Sociobiology 58, 49-66.

Ai, H., Yan, X., and Han, R. (2012b). Occurrence and prevalence of seven bee viruses in Apis mellifera and Apis cerana apiaries in China. J. Invertebr. Pathol. 1091, 160-164. doi: 10.1016/j.jip.2011.10.006

Alger, S. A., Burnham, P. A., and Brody, A. K. (2019). Flowers as viral hot spots: honey bees (Apis Mellifera) unevenly deposit viruses across plant species. PLoS One 14:e0221800. doi: 10.1371/journal.pone.0221800

Allen, M., and Ball, B. (1996). The incidence and world distribution of honey bee viruses. Bee World 77, 141-146.

Alvarez, L. J., Reynaldi, F. J., Ramello, P. J., Garcia, M. L., Sguazza, G. G. H., Abrahamovich, A. H., et al. (2018). Detection of honey bee viruses in Argentinian stingless bees (Hymenoptera: Apidae). Insectes Soc. 65, 191-197.

Alves, D. A., Imperatriz-Fonseca, V. L., Francoy, T. M., Santos-Filho, P. S., Nogueira-Neto, P., Billen, J., et al. (2009). The queen is dead - long live the workers: intraspecific parasitism by workers in the stingless bee Melipona scutellaris. Mol. Ecol. 18, 4102-4111. doi: 10.1111/j.1365-294X.2009. 04323.x

Amiri, E., Kryger, P., Meixner, M. K., Strand, M. D., Tarpy, D. R., and Rueppell, O. (2018). Quantitative patterns of vertical transmission of deformed wing virus in honey bees. PLoS One 13:e0195283. doi: 10.1371/journal.pone.019 5283

Amiri, E., Meixner, M., Büchler, R., and Kryger, P. (2014). Chronic Bee paralysis virus in honeybee queens: evaluating susceptibility and infection routes. Viruses 6, 1188-1201. doi: $10.3390 / \mathrm{v} 6031188$

Amiri, E., Meixner, M. D., and Kryger, P. (2016). Deformed wing virus can be transmitted during natural mating in honey bees and infect the queens. Sci. Rep. 6:33065. doi: 10.1038/srep33065

Amiri, E., Seddon, G., Zuluaga Smith, W., Strand, M. K., Tarpy, D. R., and Rueppell, O. (2019). Israeli acute paralysis virus: honey bee queen-worker interaction and potential virus transmission pathways. Insects 10:9. doi: 10 . 3390/insects 10050123

Bailes, E. J., Deutsch, K. R., Bagi, J., Rondissone, L., Brown, M. J. F., and Lewis, O. T. (2018). First detection of bee viruses in hoverfly (syrphid) pollinators. Biol. Lett. 14:20180001. doi: 10.1098/rsbl.2018.0001

\section{ACKNOWLEDGMENTS}

We wish to express our sincere gratitude to the honey bee research association "COLOSS" (https://coloss.org), for providing opportunity for the conception of this project and its development and funds towards the publication fee of this article. COLOSS Association is supported by the Ricola Foundation Nature and Culture and Véto-pharma. Appreciation is addressed to Lars Straub for language revision on earlier versions of the manuscript. OY would like to acknowledge the Vinetum Foundation and the Open Access Publication Fund from the University of Bern. JM wishes to acknowledge the financial support from FORMAS grant 2013-1225 and EU Horizon 2020 R\&I grant 773921. PC would like to acknowledge Chiang Mai University.

Bailey, L. (1965). The occurrence of chronic and acute bee paralysis viruses in bees outside Britain. J. Invertebr. Pathol. 7, 167-169. doi: 10.1016/0022-2011(65) 90031-5

Bailey, L. (1969). The multiplication and spread of sacbrood virus of bees. Ann. Appl. Biol. 63, 483-491. doi: 10.1111/j.1744-7348.1969.tb02844.x

Bailey, L., and Ball, B. V. (1991). Honey Bee Pathology, 2nd Edn. London: Academic Press.

Bailey, L., Ball, B. V., and Perry, J. N. (1981). The prevalence of viruses of honey bees in Britain. Ann. Appl. Biol. 97, 109-118. doi: 10.1111/j.1744-7348.1981. tb02999.x

Bailey, L., Ball, B. V., and Perry, J. N. (1983a). Association of viruses with two protozoal pathogens of the honey bee. Ann. Appl. Biol. 103, 13-20.

Bailey, L., Ball, B. V., and Perry, J. N. (1983b). Honeybee paralysis: its natural spread and its diminished incidence in England and Wales. J. Apic. Res. 22, 191-195.

Bailey, L., Carpenter, J. M., and Woods, R. D. (1979). Egypt bee virus and Australian isolates of Kashmir bee virus. J. Gen. Virol. 43, 641-647. doi: 10.1099/00221317-43-3-641

Bailey, L., and Collins, M. D. (1982). Taxonomic studies on 'Streptococcus pluton'. J. Appl. Bacteriol. 53, 209-213.

Bailey, L., and Fernando, E. F. W. (1972). Effects of sacbrood virus on adult honey-bees. Ann. Appl. Biol. 72, 27-35. doi: 10.1111/j.1744-7348.1972.tb01 268.x

Bailey, L., and Gibbs, A. J. (1964). Acute infection of bees with paralysis virus. J. Insect Pathol. 6, 395-407. doi: 10.1371/journal.pone.0073429

Bailey, L., Gibbs, A. J., and Woods, R. D. (1963). Two viruses from adult honey bees (Apis mellifera Linnaeus). Virology 21, 390-395. doi: 10.1016/0042-6822(63) 90200-9

Bailey, L., and Milne, R. G. (1969). The multiplication regions and interaction of acute and chronic bee paralysis viruses in adult honeybees. J. Gen. Virol. 4, 9-14.

Bailey, L., and Woods, R. D. (1974). Three previously undescribed viruses from the honey bee. J. Gen. Virol. 25, 175-186. doi: 10.1099/0022-1317-25-2-175

Bailey, L., and Woods, R. D. (1977). Two more small RNA viruses from honey bees and further observations on sacbrood and acute bee-paralysis viruses. J. Gen. Virol. 37, 175-182.

Bakonyi, T., Farkas, R., Szendroi, A., Dobos-Kovacs, M., and Rusvai, M. (2002). Detection of acute bee paralysis virus by RT-PCR in honey bee and Varroa destructor field samples: rapid screening of representative Hungarian apiaries. Apidologie 33, 63-74.

Ball, B. V. (1983). The association of Varroa jacobsoni with virus diseases of honey bees. Exp. Appl. Acarol. 19, 607-613.

Ball, B. V. (1985). Acute paralysis virus isolates from honeybee colonies infected with Varroa jacobsoni. J. Apic. Res. 24, 115-119.

Ball, B. V. (1989). "Varroa jacobsoni as a virus vector," in Present Status of Varroatosis in Europe and Progress in the Varroa Mite Control, ed. R. Cavalloro, (Luxemburg: EC-Experts Group).

Barbara, G. S., Grünewald, B., Paute, S., Gauthier, M., and Raymond-Delpech, V. (2008). Study of nicotinic acetylcholine receptors on cultured antennal lobe 
neurones from adult honeybee brains. Invertebr. Neurosci. 8, 19-29. doi: 10. 1007/s10158-007-0062-2

Beaurepaire, A., Piot, N., Doublet, V., Antuñez, K., Campbell, E., Chantawannakul, P., et al. (2020). Diversity and global distribution of viruses of the western honey bee, Apis mellifera. Insects 11:239. doi: 10.3390/insects11040239

Benjeddou, M., Leat, N., Allsopp, M., and Davison, S. (2002). Development of infectious transcripts and genome manipulation of Black queen-cell virus of honey bees. J. Gen. Virol. 83, 3139-3146. doi: 10.1099/0022-1317-83-12-3139

Berényi, O., Bakonyi, T., Derakhshifar, I., Köglber, H., Topolska, G., Ritter, W., et al. (2007). Phylogenetic analysis of deformed wing virus genotypes from diverse geographic origins indicates recent global distribution of the virus. Appl. Environ. Microbiol. 73, 3605-3611. doi: 10.1128/AEM.00696-07

Bergem, M., Norberg, K., and Aamodt, R. M. (2006). Long-term maintenance of in vitro cultured honeybee (Apis mellifera) embryonic cells. BMC Dev. Biol. 6:17. doi: 10.1186/1471-213X-6-17

Bigot, D., Dalmon, A., Roy, B., Hou, C., Germain, M., Romary, M., et al. (2017). The discovery of Halictivirus resolves the Sinaivirus phylogeny. J. Gen. Virol. 98, 2864-2875. doi: 10.1099/jgv.0.000957

Blanchard, P., Ribière, M., Celle, O., Lallemand, P., Schurr, F., Olivier, V., et al. (2007). Evaluation of a real-time two-step RT-PCR assay for quantitation of Chronic bee paralysis virus (CBPV) genome in experimentally-infected bee tissues and in life stages of a symptomatic colony. J. Virol. Methods 141, 7-13. doi: 10.1016/j.jviromet.2006.11.021

Bodden, J. M., Jenny, A., Hazlehurst, E., Erin, M., and Wilson, R. (2019). Floral traits predict frequency of defecation on flowers by foraging bumble bees. J. Insect Sci. 19, 4-6. doi: 10.1093/jisesa/iez091

Boncristiani, H. F., Evans, J. D., Chen, Y., Pettis, J., Murphy, C., Lopez, D. L., et al. (2013). In vitro infection of pupae with Israeli acute paralysis virus suggests disturbance of transcriptional homeostasis in honey bees (Apis mellifera). PLoS One 8:e73429. doi: 10.1371/journal.pone.0073429

Bowen-Walker, P. L., Martin, S. J., and Gunn, A. (1999). The transmission of deformed wing virus between honeybees (Apis mellifera L.) by the ectoparasitic mite varroa jacobsoni Oud. J. Invertebr. Pathol. 73, 101-106. doi: 10.1006/jipa. 1998.4807

Burnside, C. E. (1945). The cause of paralysis of honeybees. Am. Bee J. 85, 354-363.

Campbell, E. M., Budge, G. E., Watkins, M., and Bowman, A. S. (2016). Transcriptome analysis of the synganglion from the honey bee mite, Varroa destructor and RNAi knockdown of neural peptide targets. Insect Biochem. Mol. Biol. 70, 116-126. doi: 10.1016/j.ibmb.2015.12.007

Carreck, N. L., Ball, B. V., and Martin, S. J. (2010). The epidemiology of cloudy wing virus infections in honey bee colonies in the UK. J. Apic. Res. 49, 66-71.

Carrillo-Tripp, J., Bonning, B. C., and Miller, W. A. (2015). Challenges associated with research on RNA viruses of insects. Curr. Opin. Insect Sci. 8, 62-68. doi: $10.1016 /$ j.cois.2014.11.002

Carrillo-Tripp, J., Dolezal, A. G., Goblirsch, M. J., Miller, W. A., Toth, A. L., and Bonning, B. C. (2016). In vivo and in vitro infection dynamics of honey bee viruses. Sci. Rep. 6:22265. doi: 10.1038/srep22265

Celle, O., Blanchard, P., Olivier, V., Schurr, F., Cougoule, N., Faucon, J.-P., et al. (2008). Detection of Chronic bee paralysis virus (CBPV) genome and its replicative RNA form in various hosts and possible ways of spread. Virus Res. 133, 280-284. doi: 10.1016/j.virusres.2007.12.011

Chanpanitkitchote, P., Chen, Y., Evans, J. D., Li, W., Li, J., Hamilton, M., et al. (2018). Acute bee paralysis virus occurs in the Asian honey bee Apis cerana and parasitic mite Tropilaelaps mercedesae. J. Invertebr. Pathol. 151, 131-136. doi: 10.1016/j.jip.2017.11.009

Chantawannakul, P., de Guzman, L. I., Li, J., and Williams, G. R. (2016). Parasites, pathogens, and pests of honeybees in Asia. Apidologie 47, 301-324.

Chantawannakul, P., Ward, L., Boonham, N., and Brown, M. (2006). A scientific note on the detection of honeybee viruses using real-time PCR (TagMan) in Varroa mites collected from a Thai honeybee (Apis mellifera) apiary. J. Invertebr. Pathol. 91, 69-73. doi: 10.1016/j.jip.2005.11.001

Chen, Y., Evans, J., Hamilton, M., and Feldlaufer, M. (2007). The influence of RNA integrity on the detection of honey bee viruses: molecular assessment of different sample storage methods. J. Apic. Res. 46, 81-87.

Chen, Y., Pettis, J. S., and Feldlaufer, M. F. (2005). Detection of multiple viruses in queens of the honey bee Apis mellifera L. J. Invertebr. Pathol. 90, 118-121. doi: 10.1016/j.jip.2005.08.005
Chen, Y. P., Pettis, J. S., Collins, A., and Feldlaufer, M. F. (2006). Prevalence and transmission of honeybee viruses. Appl. Environ. Microbiol. 72, 606-611.

Chen, Y. P., Pettis, J. S., Corona, M., Chen, W. P., Li, C. J., Spivak, M., et al. (2014). Israeli acute paralysis virus: epidemiology, pathogenesis and implications for honey bee health. PLoS Pathog. 10:e1004261. doi: 10.1371/journal.ppat.1004261

Chen, Y. P., and Siede, R. (2007). Honey bee viruses. Adv. Virus Res. 70, 33-80.

Choe, S. E., Nguyen, L. T. K., Noh, J. H., Koh, H. B., Jean, Y. H., Kweon, C. H., et al. (2012). Prevalence and distribution of six bee viruses in Korean Apis cerana populations. J. Invertebr. Pathol. 109, 330-333. doi: 10.1016/j.jip.2012.01.003

Choi, Y. S., Lee, M. L., Lee, M. Y., and Lee, K. (2008). Occurrence of seven honeybee viruses and research of disease occurrence in Korean apiaries. Korean J. Apic. 23, 153-159.

Choi, Y. S., Lee, M. Y., Hong, I. P., Kim, N. S., Kim, H. K., Lee, K. G., et al. (2010). Occurrence of sacbrood virus in Korean apiaries from Apis cerana (Hymenoptra: Apidae). Korean J. Apic. 25, 187-191.

Core, A., Runckel, C., Ivers, J., Quock, C., Siapno, T., DeNault, S., et al. (2012). A new threat to honey bees, the parasitic phorid fly Apocephalus borealis. PLoS One 7:e29639. doi: 10.1371/journal.pone.0029639

Cornman, R. S. (2017). Relative abundance of deformed wing virus, Varroa destructor virus 1, and their recombinants in honey bees (Apis mellifera) assessed by kmer analysis of public RNA-Seq data. J. Invertebr. Pathol. 149, 44-50. doi: 10.1016/j.jip.2017.07.005

Coulon, M., Dalmon, A., Di Prisco, G., Prado, A., Arban, F., Dubois, E., et al. (2020). Interactions between thiamethoxam and Deformed wing virus can drastically impair flight behavior of honey bees. Front. Microbiol. 11:766. doi: 10.3389/fmicb.2020.00766

Coulon, M., Schurr, F., Martel, A. C., Cougoule, N., Bégaud, A., Mangoni, P., et al. (2018). Metabolisation of thiamethoxam (a neonicotinoid pesticide) and interaction with the Chronic bee paralysis virus in honeybees. Pestic. Biochem. Physiol. 144, 10-18. doi: 10.1016/j.pestbp.2017.10.009

Cox-Foster, D. L., Conlan, S., Holmes, E. C., Palacios, G., Evans, J. D., Moran, N. A., et al. (2007). A metagenomic survey of microbes in honey bee colony collapse disorder. Science 318, 283-287. doi: 10.1126/science.1146498

Dainat, B., Evans, J. D., Chen, Y. P., Gauthier, L., and Neumann, P. (2012). Predictive markers of honey bee colony collapse. PLoS One 7:e32151. doi: 10. 1371/journal.pone.0032151

Dainat, B., Evans, J. D., Chen, Y. P., and Neumann, P. (2011). Sampling and RNA quality for diagnosis of honey bee viruses using quantitative PCR. J. Virol. Methods 174, 150-152. doi: 10.1016/j.jviromet.2011.03.029

Dainat, B., Ken, T., Berthoud, H., and Neumann, P. (2009). The ectoparasitic mite Tropilaelaps mercedesae (Acari, Laelapidae) as a vector of honeybee viruses. Insectes Soc. 56, 40-43.

Dall, J. (1987). Intracellular structures associated with the multiplication of sacbrood virus. J. Invertebr. Pathol. 50, 261-268.

Dalmon, A., Desbiez, C., Coulon, M., Thomasson, M., Le Conte, Y., Alaux, C., et al. (2017). Evidence for positive selection and recombination hotspots in Deformed wing virus (DWV). Sci. Rep. 7:41045. doi: 10.1038/srep41045

Dalmon, A., Gayral, P., Decante, D., Klopp, C., Bigot, D., Thomasson, M., et al. (2019). Viruses in the invasive hornet Vespa velutina. Viruses 11:1041. doi: $10.3390 / \mathrm{v} 11111041$

D’Alvise, P., Seeburger, V., Gihring, K., Kieboom, M., and Hasselmann, M. (2019). Seasonal dynamics and co-occurrence patterns of honey bee pathogens revealed by high-throughput RT-qPCR analysis. Ecol. Evol. 9, 10241-10252. doi: 10.1002/ ece 3.5544

Danforth, B. N. (2002). Evolution of sociality in a primitively eusocial lineage of bees. Proc. Natl. Acad. Sci. U.S.A. 99, 286-290. doi: 10.1073/pnas.01238 7999

Daughenbaugh, K. F., Martin, M., Brutscher, L. M., Cavigli, I., Garcia, E., Lavin, M., et al. (2015). Honey bee infecting Lake Sinai viruses. Viruses 7, 3285-3309. doi: 10.3390/v7062772

de Miranda, J. R., Bailey, L., Ball, B. V., Blanchard, P., Budge, G. E., Chejanovsky, N., et al. (2013). Standard methods for virus research in Apis mellifera. J. Apic. Res. 52, 1-56. doi: 10.3896/ibra.1.52.4.22

de Miranda, J. R., Cornman, R. S., Evans, J. D., Semberg, E., Haddad, N., Neumann, P., et al. (2015). Genome characterization, prevalence and distribution of a macula-like virus from Apis mellifera and Varroa destructor. Viruses 7, 35863602. doi: $10.3390 / v 7072789$ 
de Miranda, J. R., Dainat, B., Locke, B., Cordoni, G., Berthoud, H., Gauthier, L., et al. (2010a). Genetic characterization of slow bee paralysis virus of the honeybee (Apis mellifera L.). J. Gen. Virol. 91, 2524-2530. doi: 10.1099/vir.0. 022434-0

de Miranda, J. R., Cordoni, G., and Budge, G. (2010b). The Acute bee paralysis virus-Kashmir bee virus-Israeli acute paralysis virus complex. J Invertebr. Pathol. 103(Suppl. 1), S30-S47. doi: 10.1016/j.jip.2009.06.014

de Miranda, J. R., and Fries, I. (2008). Venereal and vertical transmission of deformed wing virus in honeybees (Apis mellifera L.). J. Invertebr. Pathol. 98, 184-189. doi: 10.1016/j.jip.2008.02.004

de Souza, F. S., Kevill, J. L., Correia-Oliveira, M. E., de Carvalho, C. A. L., and Martin, S. J. (2019). Occurrence of deformed wing virus variants in the stingless bee melipona subnitida and honey bee Apis mellifera populations in Brazil. J. Gen. Virol. 100, 289-294. doi: 10.1099/jgv.0.001206

Di Prisco, G., Annoscia, D., Margiotta, M., Ferrara, R., Varricchio, P., Zanni, V., et al. (2016). Mutualistic symbiosis between a parasitic mite and a pathogenic virus undermines honey bee immunity and health. Proc. Natl. Acad. Sci. U.S.A. 113, 3203-3208. doi: 10.1073/pnas.1523515113

Di Prisco, G., Pennacchio, F., Caprio, E., Boncristiani, H. F., Evans, J. D., and Chen, Y. (2011). Varroa destructor is an effective vector of Israeli acute paralysis virus in the honeybee, Apis mellifera. J. Gen. Virol. 92, 151-155. doi: 10.1099/vir.0. 023853-0

Dolan, P. T., Whitfield, Z. J., and Andino, R. (2018). Mechanisms and concepts in RNA virus population dynamics and evolution. Annu. Rev. Virol. 5, 69-92. doi: 10.1146/annurev-virology-101416-041718

Dolezal, A. G., Hendrix, S. D., Scavo, N. A., Carrillo-Tripp, J., Harris, M. A., Wheelock, M. J., et al. (2016). Honey bee viruses in wild bees: viral prevalence, loads, and experimental inoculation. PLoS One 11:e166190. doi: 10.1371/ journal.pone.0166190

Doublet, V., Natsopoulou, M. E., Zschiesche, L., and Paxton, R. J. (2015). Withinhost competition among the honey bees pathogens Nosema ceranae and Deformed wing virus is asymmetric and to the disadvantage of the virus. J. Invertebr. Pathol. 124, 31-34. doi: 10.1016/j.jip.2014.10.007

Dubois, E., Dardouri, M., Schurr, F., Cougoule, N., Sircoulomb, F., and Thiéry, R. (2020). Outcomes of honeybee pupae inoculated with deformed wing virus genotypes A and B. Apidologie 51, 18-34. doi: 10.1007/s13592-019-00701-Z

Evans, H. E. (2002). A review of prey choice in bembicine sand wasps (Hymenoptera: phecidae). Neotrop. Entomol. 31, 1-11.

Evans, H. E., and O'Neill, K. M. (2007). The Sand Wasps. Cambridge, MA: Harvard University Press. doi: 10.4159/9780674036611

Evison, S. E. F., Roberts, K. E., Laurenson, L., Pietravalle, S., Hui, J., Biesmeijer, J. C., et al. (2012). Pervasiveness of parasites in pollinators. PLoS One 7:e30641. doi: 10.1371/journal.pone.0030641

Eyer, M., Chen, Y., Schäfer, M., Pettis, J., and Neumann, P. (2009). Small hive beetle, Aethina tumida, as a potential biological vector of honeybee viruses. Apidologie 40, 419-428.

Fievet, J., Tentcheva, D., Gauthier, L., de Miranda, J., Cousserans, F., Colin, M. E., et al. (2006). Localization of deformed wing virus infection in queen and drone Apis mellifera L. Virol J. 3:16. doi: 10.1186/1743-422X3-16

Figueroa, L. L., Blinder, M., Grincavitch, C., Jelinek, A., Mann, E. K., Merva, L. A., et al. (2019). Bee pathogen transmission dynamics: deposition,persistence and acquisition on flowers. Proc. R. Soc. B 286:e20190603. doi: 10.1098/rspb.2019. 0603

Forsgren, E., de Miranda, J. R., Isaksson, M., Wei, S., and Fries, I. (2009). Deformed wing virus associated with Tropilaelaps mercedesae infesting European honey bees (Apis mellifera). Exp. Appl. Acarol. 47, 87-97. doi: 10.1007/s10493-0089204- 4

Forsgren, E., Locke, B., Semberg, E., Laugen, A. T., and de Miranda, J. R. (2017). Sample preservation, transport and processing strategies for honeybee RNA extraction: influence on RNA yield, quality, target quantification and data normalization. J. Virol. Methods 246, 81-89. doi: 10.1016/j.jviromet.2017.0 4.010

Forsgren, E., Wei, S., Guiling, D., Zhiguang, L., Van Tran, T., Tang, P. T., et al. (2015). Preliminary observations on possible pathogen spill-over from Apis mellifera to Apis cerana. Apidologie 46, 265-275.

Forzan, M., Sagona, S., Mazzei, M., and Felicioli, A. (2017). Detection of deformed wing virus in Vespa crabro. Bull. Insectol. 70, 261-265.
Francis, R. M., Nielsen, S. L., and Kryger, P. (2013). Patterns of viral infection in honey bee queens. J. Gen. Virol. 94, 668-676. doi: 10.1099/vir.0. 047019-0

Fürst, M., McMahon, D. P., Osborne, J. L., Paxton, R. J., and Brown, M. J. F. (2014). Disease associations between honeybees and bumblebees as a threat to wild pollinators. Nature 506, 364-366. doi: 10.1038/nature12977

Galbraith, D. A., Fuller, Z. L., Ray, A. M., Brockmann, A., Frazier, M., Gikungu, M. W., et al. (2018). Investigating the viral ecology of global bee communities with high-throughput metagenomics. Sci. Rep. 8:8879. doi: 10.1038/s41598018-27164-z

Garigliany, M., Taminiau, B., El Agrebi, N., Cadar, D., Gilliaux, G., Hue, M., et al. (2017). Moku virus in invasive Asian Hornets, Belgium, 2016. Emerg. Infect. Dis. 23, 2109-2112. doi: 10.3201/eid2312.171080

Gascuel, J., Masson, C., Bermudez, I., and Beadle, D. J. (1994). Morphological analysis of honeybee antennal cells growing in primary cultures. Tissue Cell 26, 551-558. doi: 10.1016/0040-8166(94)90007-8

Gauthier, L., Cornman, S., Hartmann, U., Cousserans, F., Evans, J. D., de Miranda, J. R., et al. (2015). The Apis mellifera filamentous virus genome. Viruses 7, 3798-3815. doi: 10.3390/v7072798

Genersch, E., Gisder, S., Hedtke, K., Hunter, W. B., Möckel, N., and Müller, U. (2013). Standard methods for cell cultures in Apis mellifera research. J. Apic. Res. 52, 1-8. doi: 10.3896/IBRA.1.52.1.02

Genersch, E., Yue, C., Fries, I., and de Miranda, J. R. (2006). Detection of deformed wing virus, a honey bee viral pathogen, in bumble bees (Bombus terrestris and Bombus pascuorum) with Wing Deformities. J. Invertebr. Pathol. 91, 61-63. doi: 10.1016/j.jip.2005.10.002

Gisder, S., Aumeier, P., and Genersch, E. (2009). Deformed wing virus: replication and viral load in mites (Varroa destructor). J. Gen. Virol. 90, 463-467. doi: 10.1099/vir.0.005579-0

Gisder, S., and Genersch, E. (2017). Viruses of commercialized insect pollinators. J. Invertebr. Pathol. 147, 51-59. doi: 10.1016/j.jip.2016.07.010

Gisder, S., Möckel, N., Eisenhardt, D., and Genersch, E. (2018). In vivo evolution of viral virulence: switching of deformed wing virus between hosts results in virulence changes and sequence shifts. Environ. Microbiol. 20, 4612-4628. doi: 10.1111/1462-2920.14481

Giuffre, C., Lubkin, S. R., and Tarpy, D. (2019). Does viral loads alter behaviour of the bee parasite Varroa destructor? PLoS One 14:e0217975. doi: 10.1371/journal. pone. 0217975

Goblirsch, M. J., Spivak, M. S., and Kurtti, T. J. (2013). A cell line resource derived from honey bee (Apis mellifera) embryonic tissues. PLoS One 8:e69831. doi: 10.1371/journal.pone.0069831

Goldberg, F., Grünewald, B., Rosenboom, H., and Menzel, R. (1999). Nicotinic acetylcholine currents of cultured Kenyon cells from the mushroom bodies of the honey bee Apis mellifera. J. Physiol. 514, 759-768. doi: 10.1111/j.1469-7793. 1999.759ad.X

Golding, Y. C., and Edmunds, M. (2000). Behavioural mimicry of honeybees (Apis mellifera) by droneflies (Diptera: Syrphidae: Eristalis spp.). Proc. Biol. Sci. 267, 903-909. doi: 10.1098/rspb.2000.1088

Gong, H.-R., Chen, X.-X., Chen, Y. P., Hu, F.-L., Zhang, J.-L., Lin, Z.-G., et al (2016). Evidence of Apis cerana Sacbrood virus Infection in Apis mellifera. Appl. Environm. Microbiol. 82:2256.

Gonthier, J., Papach, A., Straub, L., Campbell, J., Williams, G. R., and Neumann, P. (2019). Bees and flowers: how to feed an invasive beetle species. Ecol. Evol. 9, 6422-6432. doi: 10.1002/ece3.5217

Grabensteiner, E., Ritter, W., Carter, M. J., Davison, S., Pechhacker, H., Kolodziejek, J., et al. (2001). Sacbrood virus of the honeybee (Apis mellifera): rapid indentification and phylogenetic analysis using reverse transcriptionPCR. Clin. Diagn. Lab. Immunol. 8, 93-104. doi: 10.1128/CDLI.8.1.93-10 4.2001

Grace, T. D. C. (1962). Establishment of four strains of cells from insect tissues grown in vitro. Nature 195, 788-789. doi: 10.1038/195788a0

Graystock, P., Goulson, D., and Hughes, W. O. H. (2015). Parasites in bloom: flowers aid dispersal and transmission of pollinator parasites within and between bee species. Proc R. Soc. B Biol. Sci. 282:20151371. doi: 10.1098/rspb. 2015.1371

Groden, E., Drummond, F. A., Garnas, J., and Francoeur, A. (2005). Distribution of an invasive ant, Myrmica rubra (Hymenoptera: Formicidae), in Maine. J. Econ. Entomol. 98, 1774-1784. doi: 10.1093/jee/98.6.1774 
Gusachenko, O. N., Woodford, L., Balbirnie-Cumming, K., Ryabov, E. V., and Evans, D. J. (2019). Deformed Wing Virus spillover from honey bees to bumble bees: a reverse genetic study. bioRxiv [Preprint]. doi: 10.1101/2019.12. 18.880559

Guzman-Novoa, E., Md. Hamiduzzaman, M., Anguiano-Baez, R., Correa-Benítez, A., Castañeda-Cervantes, E., and Arnold, N. I. (2015). First detection of honey bee viruses in stingless bees in North America. J. Apic. Res 55, 185-186. doi: 10.1080/00218839.2015.1100154

Hematian, A., Sadeghifard, N., Mohebi, R., Taherikalani, M., Nasrolahi, A., Amraei, M., et al. (2016). Traditional and modern cell culture in virus diagnosis. Osong Public Health Res. Perspect. 7, 77-82. doi: 10.1016/j.phrp.2015.11.011

Hoffmann, D., Pettis, J. S., and Neumann, P. (2008). Potential host shift of the small hive beetle (Aethina tumida) to bumblebee colonies (Bombus impatiens). Insect Soc. 55, 153-162.

Holway, D. A., Lach, L., Suarez, A. V., Tsutsui, N. D., and Case, T. J. (2002). The causes and consequences of ant invasions. Annu. Rev. Ecol. Syst. 33, 181-223. doi: 10.1146/annurev.ecolsys.33.010802.150444

Hung, A., and Shimanuki, H. (1999). A scientific note on the detection of kashmir bee virus in individual honeybees and Varroa jacobsoni mites. Apidologie 30, 353-354.

Hung, A. C. F. (2000). PCR detection of Kashmir bee virus in honey bee excreta. J. Apic. Res. 39, 103-106.

Hunter, W. B. (2010). Medium for development of bee cell cultures (Apis mellifera: Hymenoptera: Apidae). In Vitro Cell. Dev. Biol. Anim. 46, 83-86. doi: 10.1007/ s11626-009-9246-x

Hunter, W. B., Ikonomou, L., Schneider, Y.-J., and Agathos, S. N. (2003). Insect cell culture for industrial production of recombinant proteins. Appl. Microbiol. Biotechnol. 62, 1-20. doi: 10.1007/s00253-003-1223-9

Iqbal, J., and Mueller, U. (2007). Virus infection causes specific learning deficits in honeybee foragers. Proc. R. Soc. B Biol. Sci. 274, 1517-1521. doi: 10.1098/rspb. 2007.0022

Jin, L., Mehmood, S., Zhang, G., Song, Y., Su, S., Huang, S., et al. (2020). Visualizing Sacbrood virus of honey bees via transformation and coupling with enhanced green fluorescent protein. Viruses 12:224. doi: 10.3390/v12020224

Ju, H., and Ghil, S. (2015). Primary cell culture method for the honeybee Apis mellifera. In Vitro Cell. Dev. Biol. Anim. 51, 890-893. doi: 10.1007/s11626-0159924-9

Kevill, J. L., Highfield, A., Mordecai, G. J., Martin, S. J., and Schroeder, D. C. (2017). ABC Assay: method development and application to quantify the role of three DWV mater variants in overawinter colony losses of European honey bees. Viruses 9:314. doi: 10.3390/v9110314

Khongphinitbunjong, K., de Guzman, L. I., Tarver, M. R., Rinderer, T. E., Chen, Y. P., and Chantawannakul, P. (2015). Differential viral levels and immune gene expression in three stocks of Apis mellifera induced by different numbers of Varroa destructor. J. Insect Physiol. 72, 28-34. doi: 10.1016/j.jinsphys.2014.1 1.005

Khongphinitbunjong, K., Neumann, P., Chantawannakul, P., and Williams, G. R. (2016). The ectoparasitic mite Tropilaelaps mercedesae reduces western honey bee, Apis mellifera, longevity and emergence weight, and promotes Deformed wing virus infections. J. Invertebr. Pathol. 137, 38-42. doi: 10.1016/j.jip.2016. 04.006

Kitagishi, Y., Okumura, N., Yoshida, H., Nishimura, Y., Takahashi, J.-I., and Matsuda, S. (2011). Long-term cultivation of in vitro Apis mellifera cells by gene transfer of human c-myc proto-oncogene. In Vitro Cell Dev. Biol. Anim. 47, 451-453. doi: 10.1007/s11626-011-9431-6

Kojima, Y., Toki, T., Morimoto, T., Yoshiyama, M., Kimura, K., and Kadowaki, T. (2011). Infestation of Japanese native honey bees by tracheal mite and virus from non-native European honey bees in Japan. Microb. Ecol. 62, 895-906. doi: 10.1007/s00248-011-9947-z

Kreissl, S., and Bicker, G. (1992). Dissociated neurons of the pupal honeybee brain in cell culture. J. Neurocytol. 21, 545-556. doi: 10.1007/bf01187116

Krunici, M. D., and Stanisavljevici, L. Z. (2006). The Biology of European Orchard Bee Osmia Cornuta (Latr.) (Hymenoptera: Megachilidae). Belgrade: University of Belgrade.

Kuszewska, K., and Woyciechowski, M. (2014). Risky robbing is a job for shortlived and infected worker honeybees. Apidologie 45, 537-544.

Lamp, B., Url, A., Seitz, K., Eichhorn, J., Riedel, C., Sinn, L. J., et al. (2016). Construction and rescue of a molecular clone of deformed wing virus (DWV). PLoS One 11:e0164639. doi: 10.1371/journal.pone.0164639
Lanzi, G., de Miranda, J. R., Boniotti, M. B., Cameron, C. E., Lavazza, A., Capucci, L., et al. (2006). Molecular and biological characterization of deformed wing virus of honeybees (Apis mellifera L). J. Virol. 80, 4998-5009. doi: 10.1128/JVI. 80.10.4998-5009.2006

Leland, D. S., and Ginocchio, C. C. (2007). Role of cell culture for virus detection in the age of technology. Clin. Microb. Rev. 20, 49-78. doi: 10.1128/CMR.000 02-06

Levin, S., Galbraith, D. A., Sela, N., Erez, T., Grozinger, C. M., and Chejanovsky, N. (2017). Presence of apisrhabdovirus-1 in populations of pollinators and their parasites from two continents. Front. Microbiol. 8:2482. doi: 10.3389/fmicb. 2017.02482

Levin, S., Sela, N., and Chejanovsky, N. (2016). Two novel viruses associated with the Apis mellifera pathogenic mite Varroa destructor. Sci. Rep. 6:37710. doi: $10.1038 /$ srep37710

Levin, S., Sela, N., Erez, T., Nestel, D., Pettis, J., Neumann, P., et al. (2019). New viruses from the ectoparasite mite Varroa destructor Infesting Apis mellifera and Apis cerana. Viruses 11:94. doi: 10.3390/v11020094

Levitt, A. L., Singh, R., Cox-Foster, D. L., Rajotte, E., Hoover, K., Ostiguy, N., et al. (2013). Cross-species transmission of honey bee viruses in associated arthropods. Virus Res. 176, 232-240. doi: 10.1016/j.virusres.2013.06.013

Lhomme, P., and Hines, H. M. (2018). Ecology and evolution of cuckoo bumble bees. Ann. Entomol. Soc. Am. 112, 122-140.

Li, J., Qin, H., Wu, J., Sadd, B. M., Wang, X., Evans, J. D., et al. (2012). The prevalence of parasites and pathogens in Asian honeybees Apis cerana in China. PLoS One 7:e47955. doi: 10.1371/journal.pone.0047955

Liu, T. P. (1991). Virus-like particles in the tracheal mite, Acarapis woodi (Rennie). Apidologie 22, 213-219.

Liu, X., Zhang, Y., Yan, X., and Han, R. (2010). Prevention of Chinese sacbrood virus infection in Apis cerana using RNA interference. Curr. Microbiol. 61, 422-428. doi: 10.1007/s00284-010-9633-2

Locher, C. P., Witt, S. A., Herndier, B. G., Abbey, N. W., Tenner-Racz, K., Racz, P., et al. (2003). Increased virus replication and virulence after serial passage of human immunodeficiency virus type 2 in baboons. J. Virol. 77, 77-83. doi: 10.1128/jvi.77.1.77-83.2003

Loope, K. J., Baty, J. W., Lester, P. J., and Wilson Rankin, E. E. (2019). Pathogen shifts in a honeybee predator following the arrival of the Varroa mite. Proc. $R$. Soc. B Biol. Sci. 286:20182499. doi: 10.1098/rspb.2018.2499

Lopez-Vaamonde, C., Koning, J. W., Brown, R. M., Jordan, W. C., and Bourke, A. F. (2004). Social parasitism by male-producing reproductive workers in a eusocial insect. Nature 430, 557-560. doi: 10.1038/nature02769

Lynn, D. E. (1999). Development of insect cell lines: virus susceptibility and applicability to prawn cell culture. Method Cell Sci. 21, 173-181. doi: 10.1023/a: 1009824207045

Lynn, D. E. (2001). Novel techniques to establish new insect cell lines. In Vitro Cell. Dev. Biol. Anim. 37, 319-321. doi: 10.1007/bf02577564

Macieira, O. J. D., Chaud-Netto, J., and Zanon, A. M. (1983). Oviposition rate and relative viability of descendants from couples of Megaselia scalaris (Diptera: Phoridae) reared in different experimental conditions. Rev. Bras. Biol. 43, 223-228.

Maori, E., Lavi, S., Mozes-Koch, R., Gantman, Y., Peretz, Y., Edelbaum, O., et al. (2007). Isolation and characterization of Israeli acute paralysis virus, a dicistrovirus affecting honeybees in Israel: evidence for diversity due to intraand inter-species recombination. J. Gen. Virol. 18, 3428-3438. doi: 10.1099/vir. 0.83284-0

Maori, E., Paldi, N., Shafir, S., Kalev, H., Tsur, E., Glick, E., et al. (2009). IAPV, a bee-affecting virus associated with colony collapse disorder can be silenced by dsRNA ingestion. Insect Mol. Biol. 18, 55-60. doi: 10.1111/j.1365-2583.2009. 00847.x

Martin, S. J., and Brettell, L. E. (2019). Deformed wing virus in honeybees and other insects. Annu. Rev. Virol 6, 49-69. doi: 10.1146/annurev-virology-092818015700

Martin, S. J., Highfield, A. C., Brettell, L., Villalobos, E. M., Budge, G. E., Powell, M., et al. (2012). Global honey bee viralandscape altered by a parasitic mite. Science 336, 1304-1306. doi: 10.1126/science.12 20941

Mazzei, M., Carrozza, M. L., Luisi, E., Forzan, M., Giusti, M. S., Sagona, S., et al. (2014). Infectivity of DWV associated to flower pollen: experimental evidence of a horizontal transmission route. PLoS One 9:e113448. doi: 10.1371/journal. pone. 0113448 
Mazzei, M., Cilia, G., Forzan, M., Lavazza, A., Mutinelli, F., and Felicioli, A. (2019). Detection of replicative Kashmir bee virus and black queen cell virus in Asian hornet Vespa velutina (Lepelieter 1836) in Italy. Sci. Rep. 9:10091. doi: 10.1038/s41598-019-46565-2

Mazzei, M., Forzan, M., Cilia, G., Sagona, S., Bortolotti, L., and Felicioli, A. (2018). First detection of replicative deformed wing virus (DWV) in Vespa Velutina Nigrithorax. Bull. Insectol. 71, 211-216.

Mazzei, M., Fronte, B., Sagona, S., Carrozza, M. L., Forzan, M., Pizzurro, F., et al. (2016). Effect of 1,3-1,6 $\beta$-Glucan on natural and experimental deformed wing virus infection in newly emerged honeybees (Apis mellifera ligustica). PLoS One 11:e0166297. doi: 10.1371/journal.pone.0166297

McMahon, D. P., Fürst, M. A., Caspar, J., Panagiotis, T., Brown, M. J. F., and Paxton, R. J. (2015). A sting in the spit: widespread cross-infection of multiple RNA viruses across wild and managed bees. J. Anim. Ecol. 84, 615-624. doi: 10.1111/1365-2656.12345

McMahon, D. P., Natsopoulou, M. E., Doublet, V., Fürst, M., Weging, S., Brown, M. J. F., et al. (2016). Elevated virulence of an emerging viral genotype as a driver of honeybee loss. Proc. Biol. Sci. 283:20160811. doi: 10.1098/rspb.2016.0811

Meeus, I., de Miranda, J. R., de Graaf, D. C., Wäckers, F., and Smagghe, G. (2014). Effect of oral infection with Kashmir bee virus and Israeli acute paralysis virus on bumblebee (Bombus terrestris) reproductive success. J. Invertebr. Pathol. 121, 64-69. doi: 10.1016/j.jip.2014.06.011

Menail, A. H., Piot, N., Meeus, I., Smagghe, G., and Loucif-Ayad, W. (2016). large pathogen screening reveals first report of Megaselia Scalaris (Diptera: Phoridae) Parasitizing Apis Mellifera Intermissa (Hymenoptera: Apidae). J. Invertebr. Pathol. 137, 33-37. doi: 10.1016/j.jip.2016.04.007

Milićević, V., Radojièić, S., Kureljušić, J., Šekler, M., Nešić, K., Veljović, L., et al. (2018). Molecular detection of black queen cell virus and Kashmir bee virus in honey. AMB Express 8:128. doi: 10.1186/s13568-018-0655-7

Möckel, N., Gisder, S., and Genersch, E. (2011). Horizontal transmission of deformed wing virus: pathological consequences in adult bees (Apis mellifera) depend on the transmission route. J. Gen. Virol. 92, 370-377. doi: 10.1099/vir.0. 025940-0

Mongiardino, K. N. P., Fontanarrosa, J., Padró, I. M., and Soto, R. (2013). First Record of Megaselia Scalaris (Loew) (Diptera: Phoridae) Infesting Laboratory Stocks of Mantids (Parastagmatoptera Tessellata, Saussure). Arthropods 2, 1-6.

Mookhploy, W., Kimura, K., Disayathanoowat, T., Yoshiyama, M., Hondo, K., and Chantawannakul, P. (2015). Capsid gene divergence of black queen cell virus isolates in Thailand and Japan honey bee species. J. Econ. Entomol. 108, 1460-1464. doi: 10.1093/jee/tov102

Moore, J., Jironkin, A., Chandler, D., Burroughs, N., Evans, D. J., and Ryabov, E. V. (2011). Recombinants between Deformed wing virus and Varroa destructor virus-1 may prevail in Varroa destructor-infested honeybee colonies. J. Gen. Virol. 92, 156-161. doi: 10.1099/vir.0.025965-0

Mordecai, G. J., Brettell, L. E., Martin, S. J., Dixon, D., Jones, I. M., and Schroeder, D. C. (2016a). Superinfection exclusion and the long-term survival of honey bees in Varroa-infested colonies. ISME J. 10, 1182-1191. doi: 10.1038/ismej. 2015.186

Mordecai, G. J., Brettell, L. E., Pachori, P., Villalobos, E., Martin, M. S. J., Jones, I. M., et al. (2016b). Moku virus; a new Iflavirus found in wasps, honey bees and Varroa. Sci. Rep. 6:34983. doi: 10.1038/srep34983

Mordecai, G. J., Wilfert, L., Martin, S. J., Jones, I. M., and Schroeder, D. C. (2016c). Diversity in a honey bee pathogen: first report of a third master variant of deformed wing virus quasispecies. ISME J. 10, 1264-1273. doi: 10.1038/ismej. 2015.178

Mussen, E. C., and Furgala, B. (1977). Replication of sacbrood virus in larval and adult honeybees, Apis mellifera. J. Invertebr. Pathol. 30, 20-34.

Nasi, S., Ciarapica, R., Jucker, R., Rosati, J., and Soucek, L. (2001). Making decisions through Myc. FEBS Lett. 49o, 153-162. doi: 10.1016/S0014-5793(01) 02118-4

Natsopoulou, M. E., McMahon, D. P., Doublet, V., Frey, E., Rosenkranz, P., and Paxton, R. J. (2017). The virulent, emerging genotype B of Deformed wing virus is closely linked to overwinter honeybee worker loss. Sci. Rep. 7:5242. doi: 10.1038/s41598-017-05596-3

Neumann, P., and Elzen, P. J. (2004). The Biology of the Small Hive Beetle (Aethina Tumida, Coleoptera: Nitidulidae): gaps in Our Knowledge of an Invasive Species. Apidologie 35, 229-247. doi: 10.1051/apido:2004010

Niu, J., Cappelle, K., de Miranda, J. R., Smagghe, G., and Meeus, I. (2014). Analysis of reference gene stability after israeli acute paralysis virus infection in bumblebees Bombus terrestris. J. Invertebr. Pathol. 115, 76-79. doi: 10.1016/j. jip.2013.10.011

Niu, J., Smagghe, G., De Coninck, D. I. M., Van Nieuwerburgh, F., Deforce, D., and Meeus, I. (2016). In Vivo Study of Dicer-2-mediated immune response of the small interfering RNA pathway upon systemic infections of virulent and avirulent viruses in Bombus Terrestris. Insect Biochem. Mol. Biol. 70, 127-137. doi: $10.1016 /$ j.ibmb.2015.12.006

Noh, J. H., Reddy, K. E., Choe, S. E., Yoo, M. S., Doan, H. T. T., Kweon, C. H., et al. (2013). Phylogenetic analysis of black queen cell virus genotypes in South Korea. Virus Genes 46, 362-368. doi: 10.1007/s11262-012-0859-x

Nordström, S. (2003). Distribution of deformed wing virus within honey bee (Apis mellifera) brood cells infested with the ectoparasitic mite Varroa destructor. Exp. Appl. Acarol. 29, 293-302. doi: 10.1023/a:1025853731214

Ongus, J. R., Peters, D., Bonmatin, J.-M., Bengsch, E., Vlak, J. M., and van Oers, M. M. (2004). Complete sequence of a picornalike virus of the genus Iflavirus replicating in the mite Varroa destructor. J. Gen. Virol. 85, 3747-3755. doi: 10.1099/vir.0.80470-0

Packer, L. (1986). The biology of a subtropical population of Halictus ligatus say (Hymenoptera: Halictidae). Ethology 72, 287-298.

Peng, W., Li, J., Boncristiani, H., Strange, J. P., Hamilton, M., and Chen, Y. (2011). Host range expansion of honey bee black queen cell virus in the bumble bee, Bombus huntii. Apidologie 42, 650-658.

Pfeiffer, K. J., and Crailsheim, K. (1998). Drifting of honeybees. Insects Soc. 45, 151-167. doi: 10.1007/s000400050076

Piot, N., Meeus, I., Kleijn, D., Scheper, J., Linders, T., and Smagghe, G. (2019). Establishment of wildflower fields in poor quality landscapes enhances microparasite prevalence in wild bumble bees. Oecologia 189, 149-158. doi: 10.1007/ s00442-018-4296-y

Piot, N., Snoeck, S., Vanlede, M., Smagghe, G., and Meeus, I. (2015). The Effect of Oral Administration of DsRNA on Viral Replication and Mortality in Bombus terrestris. Viruses 7, 3172-3185. doi: 10.3390/v7062765

Posada-Florez, F., Childers, A. K., Heerman, M. C., Egekwu, N. I., Cook, S. C., Chen, Y., et al. (2019). Deformed wing virus type A, a major honey bee pathogen, is vectored by the mite Varroa destructor in a non-propagative manner. Sci. Rep. 9:12445. doi: 10.1038/s41598-019-47447-3

Power, E. F., and Stout, J. C. (2011). Organic dairy farming: impacts on insectflower interaction networks and pollination. J. Appl. Ecol. 48, 561-569. doi: 10.1111/j.1365-2664.2010.01949.x

Prodělalová, J., Moutelíková, R., and Titěra, D. (2019). Multiple virus infections in western honeybee (Apis mellifera L.) ejaculate used for instrumental insemination. Viruses 11:306. doi: 10.3390/v11040306

Ra, D. K., Jeong, C., Lee, J. H., Lee, Y. M., Kim, K. H., Han, T. H., et al. (2012). Prevalence of honeybee diseases in Incheon area in 2011. Korean J. Vet. Serv. 35, 111-117.

Ravoet, J., De Smet, L., Meeus, I., Smagghe, G., Wenseleers, T., and de Graaf, D. C. (2014). Widespread occurrence of honey bee pathogens in solitary bees. J. Invertebr. Pathol. 122, 55-58. doi: 10.1016/j.jip.2014.08.007

Ravoet, J., De Smet, L., Wenseleers, T., and de Graaf, D. C. (2015a). Genome sequence heterogeneity of Lake Sinai Virus found in honey bees and Orf1/RdRP-based polymorphisms in a single host. Virus Res. 201, 67-72. doi: 10.1016/j.virusres.2015.02.019

Ravoet, J., De Smet, L., Wenseleers, T., and de Graaf, D. C. (2015b). Vertical transmission of honey bee viruses in a Belgian queen breeding program. BMC Vet. Res. 11:61. doi: 10.1186/s12917-015-0386-9

Reddy, K. E., Noh, J. H., Kim, Y. H., Yoo, M. S., Doan, H. T. T., Ramya, M., et al. (2013). Analysis of the nonstructural and structural polyprotein regions, and complete genome sequences of Israel acute paralysis viruses identified from honeybees (Apis mellifera) in Korea. Virology 444, 211-217. doi: 10.1016/j.virol. 2013.06.012

Regoes, R. R., Nowak, M. A., and Bonhoeffer, S. (2000). Evolution of virulence in a heterogeneous host population. Evolution 54, 64-71. doi: 10.1111/j.0014-3820. 2000.tb00008.x

Remnant, E. J., Mather, N., Gillard, T. L., Yagound, B., and Beekman, M. (2019). Direct transmission by injection affects competition among RNA viruses in honeybees. Proc. R. Soc. Lond. B Biol. Sci. 286:e20182452. doi: 10.1098/rspb. 2018.2452

Remnant, E. J., Shi, M., Buchmann, G., Blacquière, T., Holmes, E. C., Beekman, M., et al. (2017). A diverse range of novel RNA viruses in geographically distinct honey bee populations. J. Virol. 91:e00158-17. doi: 10.1128/JVI.00158-17 
Ribière, M., Lallemand, P., Iscache, A.-L., Schurr, F., Celle, O., Blanchard, P., et al. (2007). Spread of infectious chronic bee paralysis virus by honeybee (Apis mellifera L.) Feces. Appl. Environ. Microbiol. 73, 7711-7716. doi: 10.1128/AEM. 01053-07

Roberts, J. M. K., Anderson, D. L., and Durr, P. A. (2018). Metagenomic analysis of Varroa-free Australian honey bees (Apis mellifera) shows a diverse Picornavirales virome. J. Gen. Virol. 99, 818-826. doi: 10.1099/jgv.0.001073

Robinson, W. H. (1975). Megaselia Scalaris (Diptera: Phoridae) associated with laboratory cockroach colonies. Proc. Entomol. Soc. Wash. 77, 384-390.

Rosenkranz, P., Aumeier, P., and Ziegelmann, B. (2010). Biology and control of Varroa destructor. J. Invertebr. Pathol. 103, S96-S119. doi: 10.1016/j.jip.2009. 07.016

Runckel, C., Flenniken, M. L., Engel, J. C., Ruby, J. G., Ganem, D., Andino, R., et al. (2011). Temporal analysis of the honey bee microbiome reveals four novel viruses and seasonal prevalence of known viruses, Nosema, and Crithidia. PLoS One 6:e20656. doi: 10.1371/journal.pone.0020656

Ryabov, E. V., Childers, A. K., Lopez, D., Grubbs, K., Posada-Florez, F., Weaver, D., et al. (2019). Dynamic evolution in the key honey bee pathogen deformed wing virus: novel insights into virulence and competition using reverse genetics. PLoS Biol. 17:e3000502. doi: 10.1371/journal.pbio.3000502

Ryabov, E. V., Christmon, K., Heerman, C. M., Posada-Florez, F., Harrison, L. R., Chen, Y., et al. (2020). Development of a honey bee RNA virus vector based on the genome of a deformed wing virus. Viruses 12:374. doi: 10.3390/v12040374

Ryabov, E. V., Fannon, J. M., Moore, J. D., Wood, G. R., and Evans, D. J. (2016). The Iflaviruses Sacbrood virus and deformed wing virus evoke different transcriptional responses in the honeybee which may facilitate their horizontal or vertical transmission. Peer J. 4:e1591. doi: 10.7717/peerj.1591

Ryabov, E. V., Wood, G. R., Fannon, J. M., Moore, J. D., Bull, J. C., Chandler, D., et al. (2014). A virulent strain of deformed wing virus (DWV) of honeybees (Apis mellifera) prevails after Varroa destructor-mediated, or in vitro, transmission. PLoS Pathog. 10:e1004230. doi: 10.1371/journal.ppat.1004230

Sammataro, D., Gerson, U., and Needham, G. (2000). Parasitic mites of honey bees: life history, implications, and impact. Annu. Rev. Entomol. 45, 519-548. doi: 10.1146/annurev.ento.45.1.519

Sanpa, S., and Chantawannakul, P. (2009). Survey of six bee viruses using RT-PCR in northern Thailand. J. Invertebr. Pathol. 100, 116-119. doi: 10.1016/j.jip.2008. 11.010

Santamaria, J., Villalobos, E. M., Brettell, L. E., Nikaido, S., Graham, J. R., and Martin, S. J. (2018). Evidence of Varroa-mediated deformed wing virus spillover in Hawaii. J. Invertebr. Pathol. 151, 126-130. doi: 10.1016/j.jip.2017.11.008

Santillán-Galicia, M. T., Ball, B. V., Clark, S. J., and Alderson, P. G. (2010). Transmission of deformed wing virus and slow paralysis virus to adult bees (Apis mellifera L.) by Varroa destructor. J. Apic. Res. 49, 141-148.

Santillán-Galicia, M. T., Ball, B. V., Clark, S. J., and Alderson, P. G. (2014). Slow bee paralysis virus and its transmission in honey bee pupae by Varroa destructor. J. Apic. Res. 53, 146-154. doi: 10.3896/IBRA.1.53.1.16

Santos, D., Mingels, L., Vogel, E., Wang, L., Christiaens, O., Cappelle, K., et al. (2019). Generation of virus- and dsRNA-derived siRNAs with speciesdependent length in insects. Viruses 11:738. doi: 10.3390/v11080738

Schläppi, D., Chejanovsky, N., Yañez, O., and Neumann, P. (2020). Foodborne transmission and clinical symptoms of honey bee viruses in ants Lasius spp. Viruses 12:321. doi: 10.3390/v120 30321

Schläppi, D., Lattrell, P., Yañez, O., Chejanovsky, N., and Neumann, P. (2019). Foodborne transmission of deformed wing virus to ants (Myrmica rubra). Insects 10:394. doi: 10.3390/insects10110394

Schoonvaere, K., Smagghe, G., Francis, F., and de Graaf, D. C. (2018). Study of the metatranscriptome of eight social and solitary wild bee species reveals novel viruses and bee parasites. Front. Microbiol. 9:177. doi: 10.3389/fmicb. 2018.00177

Sébastien, A., Lester, P. J., Hall, R. J., Wang, J., Moore, N. E., and Gruber, M. A. M. M. (2015). Invasive ants carry novel viruses in their new range and form reservoirs for a honeybee pathogen. Biol. Lett. 11:20150610. doi: 10.1098/ rsbl.2015.0610

Seitz, K., Buczolich, K., Dikunová, A., Plevka, P., Power, K., Rümenapf, T., et al. (2019). A molecular clone of Chronic Bee Paralysis Virus (CBPV) causes mortality in honey bee pupae (Apis mellifera). Sci. Rep. 9:16274. doi: 10.1038/ s41598-019-52822-1
Shah, F. A., and Shah, T. A. (1988). Thai Sacbrood disease of Apis cerana indica. Indian Bee J. 50, 110-112.

Shen, M., Cui, L. W., Ostiguy, N., and Cox-Foster, D. (2005a). Intricate transmission routes and interactions between picorna-like viruses (Kashmir bee virus and sacbrood virus) with the honeybee host and the parasitic varroa mite. J. Gen. Virol. 86, 2281-2289. doi: 10.1099/vir.0. 80824-0

Shen, M., Yang, X., Cox-Foster, D., and Cui, L. (2005b). The role of varroa mites in infections of Kashmir bee virus (KBV) and deformed wing virus (DWV) in honey bees. Virology 342, 141-149. doi: 10.1016/j.virol.2005.07.012

Singh, R., Levitt, A. L., Rajotte, E. G., Holmes, E. C., Ostiguy, N., Vanengelsdorp, D., et al. (2010). RNA viruses in hymenopteran pollinators: evidence of inter-taxa virus transmission via pollen and potential impact on Non-Apis Hymenopteran Species. PLoS One 5:e14357. doi: 10.1371/journal.pone.0014357

Snodgrass, R. E. (1956). Anatomy of the Honey Bee. New York, NY: Comstock.

Sorescu, I., Tansa, R., Gheorghe, L., Mardare, A., and Chioveanu, G. (2003). Attempts to in vitro cultivate honey bee (Apis mellifera L.) haemocytes. Stud. Res. Vet. Med. 9, 123-131.

Sun, L., Li, M., Fei, D., Hu, Y., and Ma, M. (2017). Chinese sacbrood virus infection in Apis mellifera, Shandong, China, 2016. Virus Res. 242, 96-99. doi: 10.1016/j. virusres.2017.09.014

Takahashi, J., Yoshida, T., Takagi, T., Akimoto, S., Woo, K. S., Deowanish, S., et al. (2007). Geographic variation in the Japanese islands of Apis cerana japonica and in A. cerana populations bordering its geographic range. Apidologie 38, $335-340$.

Taylor, O. M., and Cameron, S. A. (2003). Nest construction and architecture of the amazonian bumble bee (Hymenoptera: Apidae). Apidologie 34, 321-331.

Tehel, A., Brown, M. J. F., and Paxton, R. J. (2016). Impact of managed honey bee viruses on wild bees. Curr. Opin. Virol. 19, 16-22. doi: 10.1016/j.coviro.2016. 06.006

Tehel, A., Vu, Q., Bigot, D., Gogol-Döring, A., Koch, P., Jenkins, C., et al. (2019). The two prevalent genotypes of an emerging infectious disease, deformed wing virus, cause equally low pupal mortality and equally high wing deformities in host honey bees. Viruses 11:e114. doi: 10.3390/v11020114

Thaduri, S., Locke, B., Granberg, F., and de Miranda, J. R. (2018). Temporal changes in the viromes of Swedish Varroa-resistant and Varroa-susceptible honeybee populations. PLoS One 13:e0206938. doi: 10.1371/journal.pone. 0206938

Thaduri, S., Stephan, J. G., de Miranda, J. R., and Locke, B. (2019). Disentangling host-parasite-pathogen interactions in a Varroa-resistant honeybee population reveals virus tolerance as an independent, naturally adapted survival mechanism. Sci. Rep. 9:6221. doi: 10.1038/s41598-019-42741-6

Traynor, K. S., Mondet, F., de Miranda, J. R., Techer, M., Kowallik, V., Oddie, M., et al. (2020). Varroa destructor: a complex parasite, crippling bees worldwide. Trends Parasitol. 36, 5-19. doi: 10.20944/preprints202002.0374.v1

van Oers, M. M., and Lynn, D. E. (2010). "Insect cell culture," in Encyclopedia of Life Sciences, eds John Wiley \& Sons Ltd. (Chichester: ELS Language Centers). doi: 10.1002/9780470015902.a0002574.pub2

Wang, H., Meeus, I., Piot, N., and Smagghe, G. (2017). Systemic Israeli acute paralysis virus (IAPV) infection in bumblebees (Bombus terrestris) through feeding and injection. J. Invertebr. Pathol. 151, 158-164. doi: 10.1016/j.jip.2017. 11.015

Wang, L., Swevers, L., Rombouts, C., Meeus, I., Van Meulebroeck, L., Vanhaecke, L., et al. (2019). A metabolomics approach to unravel Cricket Paralysis virus infection in silkworm Bm5 Cells. Viruses 11:861. doi: 10.3390/v11090861

Wang, L.-L., Swevers, L., Van Meulebroeck, L., Meeus, I., Vanhaecke, L., and Smagghe, G. (2020). A metabolomic analysis of Cricket Paralysis virus infection in Drosophila S2 cells reveals divergent effects on central carbon metabolism as compared with silkworm Bm5 Cells. Viruses 12:393. doi: 10.3390/v12040393

Wu, Y., Dong, X., and Kadowaki, T. (2017). Characterization of the copy number and variants of deformed wing virus (DWV) in the pairs of honey bee pupa and infesting Varroa destructor or Tropilaelaps mercedesae. Front. Microbiol. 8:1558. doi: $10.3389 /$ fmicb.2017.01558

Xia, X., Mao, Q., Wang, H., Zhou, B., and Wei, T. (2014). Replication of Chinese sacbrood virus in primary cell cultures of Asian honeybee (Apis cerana). Arch. Virol. 159, 3435-3438. doi: 10.1007/s00705-014-2183-3

Yañez, O., Chávez-Galarza, J., Tellgren-Roth, C., Pinto, M. A., Neumann, P., and de Miranda, J. R. (2020). The honeybee (Apis mellifera) developmental state shapes 
the genetic composition of the deformed wing virus-A quasispecies during serial transmission. Sci. Rep. 10:e5956. doi: 10.1038/s41598-020-62673-w

Yañez, O., Jaffé, R., Jarosch, A., Fries, I., Moritz, R. A., Paxton, R., et al. (2012a). Deformed wing virus and drone mating flights in the honey bee (Apis mellifera): implications for sexual transmission of a major honey bee virus. Apidologie 43, $17-30$.

Yañez, O., Zheng, H. Q., Hu, F. L., Neuman, P., and Dietemann, V. (2012b). A scientific note on Israeli acute paralysis virus infection of Eastern honeybee Apis cerana and vespine predator Vespa velutina. Apidologie 43, 587-589.

Yañez, O., Zheng, H. Q., Su, X. L., Hu, F. L., Neumann, P., and Dietemann, V. (2016). Potential for virus transfer between the honey bees Apis mellifera and Apis cerana. J. Apic. Res. 54, 179-191.

Yang, B., Peng, G., Li, T., and Kadowaki, T. (2013). Molecular and phylogenetic characterization of honey bee viruses, Nosema microsporidia, protozoan parasites, and parasitic mites in China. Ecol. Evol. 3, 298-311. doi: 10.1002/ece 3.464

Yang, D., Zhao, H., Shi, J., Xu, X., Wu, Y., Guo, R., et al. (2019). Discovery of Aphid Lethal Paralysis Virus in Vespa velutina and Apis cerana in China. Insects 10:157. doi: 10.3390/insects10060157

Yang, S., Zhao, H., Deng, Y., Deng, S., Wang, X., Diao, Q., et al. (2020). A reverse genetics system for the Israeli acute paralysis virus and chronic bee paralysis virus. Int. J. Mol. Sci. 21:1742. doi: 10.3390/ijms 21051742

Yoo, M. S., and Yoon, B. S. (2009). Incidence on honey bee disease in Korea 2009. Korean J. Apic. 24, 273-278.

Yue, C., and Genersch, E. (2005). RT-PCR analysis of Deformed wing virus in honeybees (Apis mellifera) and mites (Varroa destructor). J. Gen. Virol. 86, 3419-3424. doi: 10.1099/vir.0.81401-0
Yue, C., Schröder, M., Bienefeld, K., and Genersch, E. (2006). Detection of viral sequences in semen of honeybees (Apis mellifera): evidence for vertical transmission of viruses through drones. J. Invertebr. Pathol. 92, 105-108. doi: 10.1016/j.jip.2006.03.001

Yue, C., Schröder, M., Gisder, S., and Genersch, E. (2007). Vertical-transmission routes for deformed wing virus of honeybees (Apis mellifera). J. Gen. Virol. 88, 2329-2336. doi: 10.1099/vir.0.83101-0

Zhang, X., He, S. Y., Evans, J. D., Pettis, J. S., Yin, G. F., and Chen, Y. P. (2012). New evidence that deformed wing virus and black queen cell virus are multi-host pathogens. J. Invertebr. Pathol. 109, 156-159. doi: 10.1016/j.jip.2011. 09.010

Zioni, N., Soroker, V., and Chejanovsky, N. (2011). Replication of Varroa destructor virus 1 (VDV-1) and a Varroa destructor virus 1-deformed wing virus recombinant (VDV-1-DWV) in the head of the honey bee. Virology 417, 106-112. doi: 10.1016/j.virol.2011. 05.009

Conflict of Interest: The authors declare that the research was conducted in the absence of any commercial or financial relationships that could be construed as a potential conflict of interest.

Copyright (c) 2020 Yañez, Piot, Dalmon, de Miranda, Chantawannakul, Panziera, Amiri, Smagghe, Schroeder and Chejanovsky. This is an open-access article distributed under the terms of the Creative Commons Attribution License (CC BY). The use, distribution or reproduction in other forums is permitted, provided the original author(s) and the copyright owner(s) are credited and that the original publication in this journal is cited, in accordance with accepted academic practice. No use, distribution or reproduction is permitted which does not comply with these terms. 